\title{
Sistematični pregled dejavnikov učinkovitosti računalniškega kognitivnega treninga pri otrocih z motnjo pozornosti s hiperaktivnostjo
}

\author{
Sara Mičič ${ }^{*}$, Vojko Kavčič ${ }^{2,3}$ in Karin Bakračevičcl \\ ${ }^{1}$ Oddelek za psihologijo, Filozofska fakulteta, Univerza v Mariboru \\ ${ }^{2}$ Institute of Gerontology, Wayne State University, Detroit, Michigan, ZDA \\ ${ }^{3}$ Mednarodni inštitut za aplikativno gerontologijo, Ljubljana
}

Povzetek: Računalniški kognitivni treningi (RKT) za otroke z motnjo pozornosti s hiperaktivnostjo (ADHD) so namenjeni premagovanju specifičnih primanjkljajev in zmanjševanju simptomov, povezanih z motnjo pozornosti. Tovrstni treningi postajajo vse bolj razširjeni in raziskani, vendar še ni povsem jasno, kako učinkovito vplivajo na generalizirane funkcionalne primanjkljaje, kot so pomanjkanje pozornosti, impulzivnost, pomanjkanje inhibicije na področju vedenja ter primanjkljaji na področju načrtovanja in organizacije. Primanjkljaji na področju izvršilnih sposobnosti, kamor spadajo tudi primanjkljaji na področju delovnega spomina, predstavljajo pomemben del ADHD in morda predstavljajo tudi osnovo za ostale simptome ADHD kamor spadajo težave na področju pozornosti, motivacije, aktivnosti in težave na področju vedenja. Zato v literaturi pogosto zasledimo RKT izvršilnih sposobnosti in delovnega spomina, ki predpostavljajo, da lahko s pomočjo njihovega izboljšanja zmanjšamo simptome ADHD. Namen pričujočega prispevka je pregledati in kritično ovrednotiti raziskave s področja RKT za otroke z ADHD in ugotoviti, ali so se tovrstni treningi v predhodnih raziskavah pokazali kot učinkoviti pri premagovanju primanjkljajev, ki so najpogostejši pri otrocih z ADHD, ter kateri tip RKT se v predhodnih raziskavah kaže kot učinkovit. Raziskovalne članke za ta prispevek smo iskali s pomočjo podatkovnih baz, vključenih v skupino EBSCOhost, in v bazah Science Direct ter Web of Science. Raziskave kažejo, da ima RKT potencialno pozitiven učinek na kognitivne sposobnosti otrok z ADHD. Nekatere študije so pokazale tudi pozitiven učinek na zmanjšanje disfunkcionalnega in impulzivnega vedenja. Vendar pa študije niso povsem enotne v obsegu vpliva RKT na tovrstne simptome, prav tako se razlikujejo $\mathrm{v}$ uporabljenem tipu RKT.

Ključne besede: motnja pozornosti s hiperaktivnostjo (ADHD), računalniški kognitivni trening (RKT), izvršilne sposobnosti, delovni spomin, otroci

\section{A systematic review of efficacy of computer-based cognitive training in children with attention deficit and hyperactivity disorder}

\author{
Sara Mičič $\check{c}^{*}$, Vojko Kavčič $\check{c}^{2,3}$ and Karin Bakračevič ${ }^{1}$ \\ ${ }^{1}$ Department of Psychology, Faculty of Arts, University of Maribor, Slovenia \\ ${ }^{2}$ Institute of Gerontology, Wayne State University, Detroit, Michigan, USA \\ ${ }^{3}$ International Institute of Applied Gerontology, Ljubljana, Slovenia
}

\begin{abstract}
Computerized cognitive training (CCT) paradigms for children with attention deficit hyperactivity disorder (ADHD) are designed to overcome specific deficits and reduce symptoms of the disorder. Such training is increasingly being researched, but it is not entirely clear how it affects generalised functional deficits, such as attention deficit, impulsivity, lack of behavioural inhibition, planning, and organisation. Executive functions deficits, which include working memory deficits, make up a large part of ADHD and may be the basis for other symptoms of the disorder, such as attention impairment, lack of motivation, hyperactivity, and conduct problems. Therefore, many studies on training executive functions and working memory assume that improving these functions can reduce ADHD symptoms. The purpose of this paper is to review and critically evaluate research in the area of CCT for children with ADHD and determine whether CCT has shown promising results in overcoming ADHD-related deficits in previous studies and what type of CCT is most promising. The articles included in this systematic review were found through databases in EBSCOhost, Science Direct, and Web of Science. Studies showed that CCT has the potential to improve cognitive functions in children with ADHD. Some studies also showed a reduction in dysfunctional and impulsive behaviours. However, the studies are not congruent regarding the CCT effects on these symptoms and they also differ in the type of CCT used.
\end{abstract}

Keywords: Attention deficit hyperactivity disorder (ADHD), computerized cognitive training, executive functions, working memory, children

"Naslov/Address: Sara Mičič, Oddelek za psihologijo, Filozofska fakulteta, Univerza v Mariboru, Koroška cesta 160, 2000 Maribor, e-mail: sara.micic1@guest.um.si

Članek je licenciran pod pogoji Creative Commons Attribution 4.0 International licence. (CC-BY licenca).

The article is licensed under a Creative Commons Attribution 4.0 International License (CC-BY license). 


\section{Značilnosti motnje pozornosti s hiperaktivnostjo ali brez nje}

Motnja pozornosti s hiperaktivnostjo (ADHD; angl. attention deficit hyperactivity disorder) ali brez nje (ADD; angl. attention deficit disorder) je motnja, ki se praviloma pojavi v otroštvu (Sonuga-Barke idr., 2014) in jo označuje vzorec težav na področju pozornosti, impulzivnosti in/ali hiperaktivnosti, pogosto pa se nadaljuje tudi $\mathrm{v}$ kasnejših razvojnih obdobjih (Barkley, 2018; Sonuga-Barke idr., 2014). Predstavlja eno izmed najpogostejših motenj v obdobju otroštva (Bikic idr., 2018). Motnja pozornosti je kompleksna in heterogena motnja, ki se od posameznika do posameznika lahko razlikuje v stopnji izraženosti simptomov, starosti ob začetku motnje, situacijsko povezanim pojavljanjem simptomov in $\mathrm{v}$ stopnji sopojavnosti $\mathrm{z}$ drugimi motnjami (Barkley, 2018).

Populacija posameznikov $\mathrm{z}$ motnjo pozornosti je heterogena tudi $\mathrm{z}$ vidika njihovega specifičnega profila nevropsiholoških primanjkljajev, pri čemer se pri posameznikih kažejo različne nevropsihološke značilnosti, kar kaže na to, da morda obstajajo različni podtipi motnje pozornosti $\mathrm{z}$ različnimi kognitivnimi, motivacijskimi in drugimi primanjkljaji (Nigg, 2005). Simptomi zajemajo primanjkljaje na področju izvršilnih sposobnosti (Rapport idr., 2013), pozornosti (Barkley, 2018), motivacije (SonugaBarke, 2011), samoregulacije in nadzora vedenja (Manly idr., 2001). ADHD je v veliki meri povezana $z$ atipičnim delovanjem prefrontalnega korteksa in povezav prefrontalnega korteksa z drugimi možganskimi področji (Durston idr., 2011).

Uradni kriteriji za motnjo pozornosti s hiperaktivnostjo ali brez nje so opisani v peti izdaji DSM (DSM-5; American Psychiatric Association, 2013, citirano v: Roberts idr., 2018). DSM-5 diagnostični kriteriji ločujejo med področjema 1) nepozornosti in 2) hiperaktivnosti ter impulzivnosti. $\mathrm{Na}$ obeh področjih se za postavitev diagnoze upošteva prisotnost šest ali več simptomov, ki so prisotni vsaj šest mesecev, so razvojno odstopajoči in posameznika ovirajo pri doseganju socialnih in akademskih aktivnosti ter dosežkov. Med diagnostične kriterije na področju nepozornosti spadajo naslednji simptomi:

(a) težave pri vzdrževanju pozornosti na podrobnosti, pojavljanje napak pri šolskem delu, delu ali pri drugih aktivnostih (npr. spregleda detajle, delo je nenatančno); (b) težave $\mathrm{z}$ ohranjanjem pozornosti pri nalogah ali igri (npr. ima težave $\mathrm{z}$ ohranjanjem pozornosti med poukom, pogovorih ali daljšem branju); (c) ne posluša, ko je ogovorjen (se zdi z mislimi drugje, tudi ob odsotnosti drugih očitnih motenj iz okolja); (d) težave s sledenjem navodilom in pri opravljanju šolskih nalog ali drugih opravil (začne z aktivnostjo, vendar hitro izgubi osredotočenost, je odkrenljiv); (e) težave $\mathrm{z}$ organiziranjem nalog ali aktivnosti (težave pri opravljanju zaporednih nalog, težave pri vzdrževanju reda pri svojih stvareh, neorganizirano delo, težave $\mathrm{z}$ načrtovanjem časa in neupoštevanje rokov); (f) pogosto izogibanje ali izražanje odpora do nalog, ki zahtevajo mentalni napor (npr. opravljanje šolskih nalog, domačih nalog, priprava poročil, izpolnjevanje obrazcev, pregled daljših besedil); (g) pogosto izgubljanje stvari, ki so potrebne za dokončanje naloge (šolskih potrebščin, knjig, pisal, pripomočkov, denarnic, ključev, dokumentov, očal, mobilnih telefonov); (h) pogosta odkrenljivost zaradi zunanjih dražljajev (pri adolescentih in odraslih lahko vključuje nepovezane misli); (i) pozabljivost med dnevnimi aktivnostmi (opravljanje opravil, pri adolescentih in odraslih lahko vključuje vračanje $\mathrm{k}$ pouku, plačevanje računov in sledenje terminom; DSM-5; American Psychiatric Association, 2013, citirano v: Roberts idr., 2018, str. 52).

Med diagnostične kriterije na področju hiperaktivnosti in impulzivnosti spadajo:

(a) pogosta nemirnost rok ali nog, zvijanje na stolu; (b) vstajanje $\mathrm{z}$ mesta $\mathrm{v}$ času, ko se pričakuje, da bo pri miru (npr. zapuščanje svojega mesta $\mathrm{v}$ razredu, $\mathrm{v}$ pisarni ali $\mathrm{v}$ drugih situacijah, ki zahtevajo mirno sedenje); (c) pogosto tekanje naokrog ali plezanje v za to neprimernih situacijah (pri adolescentih in odraslih je lahko omejeno na subjektivno občutenje nemira); (d) pogosta nezmožnost tihega igranja ali ukvarjanja s prostočasnimi aktivnostmi v tišini; (e) je ves čas v gibanju (nezmožnost biti pri miru dlje časa, npr. v restavraciji, na sestanku itd.); (f) veliko govori; g) pogosto zelo hitro odgovori na vprašanje, še preden je vprašanje do konca zastavljeno (dokončuje stavke drugih, ne more počakati, da je na vrsti med pogovorom); (h) težave pri čakanju na vrsto (npr. med čakanjem v koloni); (i) prekinjanje drugih (vskoči v pogovor, igro ali aktivnost, lahko začne uporabljati stvari drugih, brez dovoljenja, za adolescente in odrasle lahko gre za prevzemanje aktivnosti drugih) (DSM-5; American Psychiatric Association, 2013, citirano v: Roberts idr., 2018, str. 52).

Za diagnozo motnje pozornosti s hiperaktivnostjo ali brez nje je potreben pogoj tudi pojavljanje več simptomov pred 12. letom starosti. Ti se morajo pojavljati $\mathrm{v}$ različnih okoljih (npr. doma, v šoli, s prijatelji, s sorodniki in pri drugih aktivnostih); prav tako mora biti očitno, da simptomi otroka ovirajo pri socialnih, akademskih in drugih aktivnostih.

\section{Primanjkljaji na področju izvršilnih sposobnosti}

Izvršilne sposobnosti predstavljajo širok konstrukt, ki se nanaša na različne procese, med katere spadajo pozornost, delovni spomin, fleksibilnost mišljenja, načrtovanje in regulacija ciljno usmerjenih vedenj (Beck idr., 2010). Izvršilne funkcije omogočajo posameznikovo regulacijo vedenja, mišljenja in čustvovanja, kar je med drugim povezano tudi s samokontrolo (Durston idr., 2011). Primanjkljaji na področju izvršilnih sposobnosti so osnova za vse primanjkljaje, ki se pojavljajo pri ADHD in igrajo pomembno vlogo pri pojasnjevanju težav, s katerimi se vsakodnevno srečujejo otroci z ADHD (Rapport idr., 2013).

Primanjkljaji na področju izvršilnih sposobnosti so povezani s primanjkljaji na področju pozornosti, hiperaktivnosti in impulzivnosti (Burgess idr., 2010; Kofler idr., 2010), prav tako pa tudi s tem povezanimi težavami, npr. 
s težavami na področju akademskih dosežkov (Biederman, 2004). Biederman idr. (2004) so v raziskavi preučevali povezavo med primanjkljaji na področju izvršilnega funkcioniranja in vsakodnevnim funkcioniranjem pri otrocih in adolescentih z ADHD. Ugotovili so, da je statistično pomembno več udeležencev z ADHD imelo primanjkljaje na področju izvršilnih sposobnosti (primanjkljaje na vsaj dveh področjih izvršilnih sposobnosti) $\mathrm{v}$ primerjavi s kontrolno skupino brez diagnosticirane ADHD. Pri posameznikih z ADHD, pri katerih so bili prepoznani primanjkljaji na področju izvršilnega funkcioniranja, se je pokazalo tudi pomembno večje tveganje za slabše akademske dosežke.

Simptomi ADHD, predvsem simptomi na področju pozornosti, se pogosto povezujejo s primanjkljaji na področju delovnega spomina (Chacko idr., 2014). Obstaja hipoteza, da slabši delovni spomin pri posameznikih z ADHD vpliva na primanjkljaje na področju kontrole pozornosti in izvršilnih sposobnosti (Rapport idr., 2008). Delovni spomin predstavlja sposobnost začasnega shranjevanja omejenega števila informacij (Klingberg idr., 2002) z namenom aktivnega upravljanja s temi informacijami. Omogoča opravljanje različnih vrst kompleksnih aktivnosti, kot so učenje, sklepanje in odločanje (Baddeley in Hitch, 1974). Učinkovito delovanje delovnega spomina predstavlja osnovo za delovanje različnih kognitivnih funkcij, zato je ključnega pomena za uspešno funkcioniranje $\mathrm{v}$ vsakdanjem življenju. Baddeley in Hitch (1974) sta v svojem multikomponentnem modelu delovnega spomina delovni spomin opisala kot sistem, ki ga sestavljajo centralni izvršitelj in dva podsistema (fonološka zanka in vidno-prostorska skicirka), Baddeley (2000) pa je dodal še tretji podsistem, tj. epizodični medpomnilnik. Naloga centralnega izvršitelja je uravnavanje pozornosti, nadzorovanje fonološke zanke in vidno-prostorske skicirke, pri čemer vodi pritok informacij, koordinira hkratno izvrševanje nalog in omogoča komunikacijo z dolgoročnim spominom. Fonološka zanka začasno shranjuje slušne in verbalne informacije ter ima pomembno vlogo pri pomnjenju zaporedja števil. Vidno-prostorska skicirka začasno shranjuje vidno-prostorske informacije in je pomembna pri prostorski orientaciji in reševanju vidno-prostorskih problemov. Epizodični medpomnilnik pa omogoča začasno shranjevanje večmodalnih informacij in združevanje informacij iz obeh podsistemov in dolgoročnega spomina v enotno reprezentacijo epizode. Rapport idr. (2008) so v raziskavi ugotovili, da se pri posameznikih z ADHD pojavljajo motnje, povezane $\mathrm{z}$ vsemi tremi komponentami Baddeleyjevega in Hitchevega (1974) modela delovnega spomina. Ugotovili so sicer, da so primanjkljaji na področju centralnega izvršitelja bolj izraženi kot primanjkljaji obeh sistemov shranjevanja. Na podlagi rezultatov avtorji poudarjajo pomembnost vloge centralnega izvršitelja pri usmerjanju in ohranjanju pozornosti in nadzorovanju obeh podsistemov in ugotavljajo, da se na tem področju kažejo večji primanjkljaji pri posameznikih $z$ ADHD.

V skladu z ugotovitvami nekaterih raziskav (npr. Rapport idr., 2008) se v zadnjem času povečuje število raziskav na področju razvojne psihologije in kognitivne nevroznanosti, ki se ukvarjajo $\mathrm{z}$ nadzorom pozornosti kot glavnim mehanizmom omejitve kapacitete kratkoročnega spomina in delovnega spomina (Astle in Scerif, 2011). Literatura na tem področju (npr. Manly idr., 2001) poudarja razliko med povezanimi, vendar razmeroma ločenimi procesi pozornosti, kot so vzdrževanje pozornosti (sposobnost ohranjanja pozornosti na cilju naloge $\mathrm{v}$ nekem časovnem obdobju), selektivna pozornost (sposobnost izbiranja $\mathrm{z}$ nalogo povezanih informacij med irelevantnimi dražljaji) in izvršilna pozornost oz. nadzor pozornosti (sposobnost nadzora odgovora na dražljaje, povezane s ciljnim dražljajem, in potencialno relevantnih informacij). Manly idr. (2001) poudarjajo predvsem primanjkljaje pri posameznikih $\mathrm{z}$ ADHD na področju vzdrževanja pozornosti in na področju nadzora pozornosti in inhibicije motečih dražljajev.

\section{Primanjkljaji na področju motivacije}

Poleg primanjkljajev na področju izvršilnih sposobnosti imajo otroci z ADHD lahko težave tudi na področju motivacije. Motivacijski modeli (npr. Sonuga-Barke, 2011) predpostavljajo, da ojačevanje vedenja (npr. nagrajevanje) otroke z ADHD stimulira v manjši meri kot ostale otroke. Predvidevajo, da se manjša stimulacija pojavi zaradi posebnosti delovanja dopaminergičnega sistema. Pri otrocih z ADHD naj bi ob zunanjih ojačevalcih (npr. nagradah) prišlo do zmanjšanja ravni dopamina $\mathrm{v}$ možganskih centrih, ki so povezani $\mathrm{z}$ nagrajevanjem. Zmanjšanje dopamina vpliva na zmanjšanje nadzora pozornosti, zmanjšano inhibicijo neprimernega odziva in znižanje motivacije za odziv na nagrado. Otroci z ADHD potrebujejo večjo količino in večjo pogostnost nagrajevanja, da dosežejo optimalno izvedbo. Ta povečana potreba po ojačevanju lahko vpliva na težave $\mathrm{z}$ motivacijo med kognitivnim treningom (Dovis idr., 2015).

Dovis idr. (2012) so v raziskavi preverjali predpostavko, da so primanjkljaji na področju izvršilnih sposobnosti pri otrocih $\mathrm{z}$ motnjo pozornosti povezani $\mathrm{z}$ motivacijskimi primanjkljaji. Želeli so preveriti učinek različnih ojačitev na izvedbo naloge delovnega spomina pri 30 otrocih $\mathrm{z}$ motnjo pozornosti s hiperaktivnostjo in 31 otrocih brez diagnosticirane motnje. Uspešnost na nalogi vidnoprostorskega delovnega spomina pri posameznem poskusu so nagradili z enim izmed štirih načinov ojačevanja: povratno informacijo, povratno informacijo in manjšo spodbudo (1 evro), povratno informacijo in večjo spodbudo (10 evrov) in nalogo delovnega spomina $\mathrm{v}$ obliki računalniške igrice. Pri pogoju, ko so udeleženci dobili le povratno informacijo (vidno povratno informacijo o uspešnosti na nalogi, prisotno ves čas opravljanja naloge), so imeli otroci z motnjo pozornosti na nalogi delovnega spomina slabše rezultate $\mathrm{v}$ primerjavi $\mathrm{s}$ kontrolno skupino. Večje spodbude so pomembno izboljšale izvedbo na nalogi pri otrocih z ADHD. Prav tako se je pri otrocih z ADHD pokazala manjša učinkovitost izvedbe po daljšem času izvajanja, le pri večjih spodbudah (10 evrih in računalniški igrici) je njihova izvedba po daljšem času ostajala stabilna, medtem ko manjša spodbuda z 1 evrom ni imela učinka. Avtorji so tako na podlagi rezultatov zaključili, da se težave pri vztrajanju pri določeni nalogi pri otrocih z ADHD pojavijo zaradi primanjkljajev na področju motivacije. 


\section{Nadzor vedenja, samoregulacija in regulacija čustev}

Za razumevanje motnje pozornosti s hiperaktivnostjo ali brez nje je prav tako pomembno upoštevanje težav na področju izvršilne in kognitivne inhibicije ter regulacije čustev, še posebej tistih, ki so povezane z regulacijo občutij frustracije, nepotrpežljivosti in jeze (Barkley, 2018). Težave $\mathrm{z}$ regulacijo čustev in čustvena impulzivnost so namreč pogoste pri posameznikih z diagnosticirano ADHD. Regulacija čustev je proces nadzorovanja, vrednotenja in prilagajanja čustvenih reakcij (Forslund idr., 2016). Čustvena impulzivnost se nanaša na hitrost in verjetnost, $\mathrm{s}$ katero se bo posameznik v primerjavi z ostalimi osebami v enakem razvojnem obdobju na situacijo odzval s primarnim (najpogosteje negativnim) čustvom (Barkley, 2018). Primarna čustvena reakcija posameznikov z diagnozo ADHD ne odstopa v intenziteti, temveč v manjši zavedni samoregulaciji čustev.

Primanjkljaji na področju inhibicije čustvenega odziva kot tudi neprimernega vedenjskega odziva (Sonuga-Barke, 2005) so v literaturi pogosto omenjeni kot nevropsihološka značilnost posameznikov $\mathrm{z}$ motnjo pozornosti $\mathrm{s}$ hiperaktivnostjo, ki je povezana s simptomi motnje (Willcut idr., 2005). Pri posameznikih z ADHD tako lahko govorimo o zmanjšani inhibiciji na kognitivni, vedenjski ali čustveni ravni (Solanto, 2018). Vendar pa ni povsem jasno, kako so te ravni funkcioniranja med seboj povezane. Forslund idr. (2016) ugotavljajo, da je kognitivna inhibicija povezana s simptomi ADHD, vendar neodvisno od regulacije čustev. Forslund idr. so preučevali različne načine čustvenega funkcioniranja, ki so povezani z ADHD simptomi in vedenjskimi težavami, in ugotovili, da so primanjkljaji na področju regulacije čustev in pogostost negativnega čustvovanja povezani $\mathrm{s}$ komorbidnimi vedenjskimi težavami. Raziskava namreč ni pokazala neposredne povezave med kognitivno inhibicijo in vedenjskimi težavami. Prav tako so avtorji ugotovili, da se negativna čustva povezujejo $\mathrm{z}$ vedenjskimi težavami, ne pa $\mathrm{s}$ simptomi ADHD.

\section{Sopojavnost ADHD in ADD z drugimi motnjami}

ADHD in ADD se pogosto pojavljata $\mathrm{z}$ drugimi motnjami (t. i. sopojavnost oz. komorbidnost), kar lahko otežuje proces diagnostike, hkrati pa pri raziskovanju vpliva različnih intervencij oteži prepoznavanje učinkov intervencije na različne primanjkljaje, ki se lahko v primeru komorbidnosti pojavijo. Mohammadi idr. (2019) ugotavljajo, da se komorbidna motnja pojavi pri 61,5\% vseh posameznikov z ADHD. Natančneje, ugotovili so, da se ADHD najpogosteje pojavlja skupaj z anksioznimi motnjami (v 37,9 \%) in vedenjskimi motnjami (v $31 \%$ ). Po njihovih podatkih se razpoloženjske in anksiozne motnje pogosteje pojavljajo $\mathrm{v}$ kombinaciji $\mathrm{z}$ ADHD pri deklicah, medtem ko je pri dečkih pogostejša komorbidna vedenjska motnja. Vzroke za komorbidnost v literaturi največkrat povezujejo z dejavniki tveganja, ki si jih obe motnji, ko se pojavita skupaj, delita (McGrath idr., 2011).

Podobno se tudi specifične učne težave (SUT) in ADHD po nekaterih ocenah pri $25 \%$ do $40 \%$ primerov pojavljata skupaj (Willcut in Pennington, 2000). Sopojavnost ADHD in SUT v literaturi pogosto pojasnjujejo s hipotezo »modela multiplih deficitov«, ki pravi, da lahko sopojavljanje obeh motenj pripišemo skupnim genetskim dejavnikom, ki povečajo občutljivost za obe motnji (McGrath idr., 2011). A. Jakobson in E. Kikas (2007) sta preučevali uspešnost treh skupin 7-10-letnih otrok (skupine otrok z ADHD, skupine otrok $\mathrm{s}$ pridruženimi primanjkljaji na področju učenja in skupine brez primanjkljajev) pri reševanju nalog spomina, vidno-prostorskih in verbalnih sposobnosti ter fine motorike. Ugotovili sta, da so otroci z ADHD dosegali slabše rezultate kot kontrolna skupina brez diagnoze ADHD in brez pridruženih primanjkljajev na področju učenja, vendar pa so bili uspešnejši od skupine z ADHD in pridruženimi primanjkljaji na področju učenja (z izjemo sposobnosti fine motorike).

ADHD se lahko sopojavlja tudi z motnjami avtističnega spektra (MAS). Obe motnji sta $\mathrm{v}$ veliki meri povezani $\mathrm{s}$ težavami na področju inhibicije odziva in težavami na socialnem področju. Težave na socialnem področju pa se povezujejo s primanjkljaji na področju izvršilnih sposobnosti (Mihevc in Vervega, 2019). Mihevc in Vervega povzemata, da podatki, pridobljeni pri kliničnih vzorcih, kažejo, da se pri vsaj $10 \%$ otrok z ADHD pojavijo tudi simptomi MAS. Študije ugotavljajo, da imata motnji številne skupne kognitivne in vedenjske simptome, zaradi česar predpostavljajo, da obstaja nek tretji neodvisni dejavnik oz. skupna genetska osnova (Matson idr., 2013).

\section{Računalniški kognitivni treningi za otroke z ADHD in ADD}

Raziskave kažejo, da izvršilno funkcioniranje in s tem povezana možganska aktivnost nista nespremenljiva, ampak se lahko spreminjata $\mathrm{s}$ pomočjo ponavljanja nalog ali treningom (Klingberg, 2010). Kognitivni trening temelji na konceptu nevroplastičnosti, ki predpostavlja, da se lahko možgani spreminjajo in reorganizirajo na podlagi novih izkušenj (Bikic idr., 2018). Willis in Schaie (2009) pravita, da »definicija kognitivne plastičnosti navadno zajema kontrast med posameznikovo trenutno stopnjo izvedbe pod normativnimi pogoji in posameznikovim latentnim potencialom« (str. 375). Raziskovalci, ki preučujejo učinek kognitivnega treninga na različne kognitivne sposobnosti, predpostavljajo, da lahko na podlagi učinkov treninga zmanjšamo simptome in izboljšamo funkcioniranje posameznika (Bikic idr., 2018). Po Baltesu (1987) obstajajo trije vidiki kognitivne izvedbe naloge: (1) osnovna izvedba, ki se nanaša na enkratno merjenje kognitivnih funkcij brez intervencije; (2) osnovna kapaciteta rezerve, ki se nanaša na trenutni maksimalni potencial posameznikovega kognitivnega sistema - ta potencial lahko aktivirajo pogoji, ki zagotavljajo optimalno izvedbo naloge (npr. kognitivni trening), in (3) razvojna kapaciteta rezerve ali razvojna plastičnost, ki predstavlja raven kognitivne izvedbe pod optimalnimi pogoji in kot rezultat intervencije $\mathrm{z}$ namenom spreminjanja posameznikovega kognitivnega sistema.

Pri uporabi kognitivnega treninga kot pogoja, ki omogoča optimalno izvedbo naloge in ima potencial za izboljšanje funkcioniranja posameznika $\mathrm{s}$ primanjkljaji na različnih 
področjih, je glavni cilj doseči izboljšanje na neposredno treniranih funkcijah, kot sta pozornost in delovni spomin (bližnji transfer), in, še pomembneje, na kognitivnih funkcijah in simptomih, ki niso bile trenirane (daljni transfer) (Bikic idr., 2018). Naloge bližnjega transfera so naloge, ki imajo z nalogo, ki je bila vključena v trening, več skupnih značilnosti kot naloge daljnega transfera, ki imajo s trenirano nalogo manj skupnih značilnosti in je možnost, da pride do transfera na te naloge, manjša (Borella idr., 2010).

Sonuga-Barke idr. (2014) pa ločujejo med dvema tipoma kognitivnih treningov. Prvi tip temelji na procesu in na posrednem učinku vaje s ponavljanjem kognitivne naloge (npr. trening hitrosti procesiranja informacij in inhibicije), primarne mentalne aktivnosti (npr. trening induktivnega sklepanja, prostorske orientacije in epizodičnega spomina), kognitivne strukture višjega reda (npr. trening fluidne inteligentnosti in izvršilnih funkcij) in globalne kognicije, ki vsebuje različne kognitivne domene, kot so pozornost in delovni spomin (Willis in Schaie, 2009). Drugi tip kognitivnega treninga pa zajema pristope, ki temeljijo na strategiji, ki uporablja neposredna navodila za naloge, ki izboljšajo izvedbo splošnih metakognitivnih spretnosti ali specifičnih strategij, kot so ponavljanje, povezovanje informacij $\mathrm{v}$ skupine (angl. chunking) ali mentalne reprezentacije (Jolles in Crone, 2012).

Računalniški kognitivni treningi (v nadaljevanju RKT), npr. RKT delovnega spomina ali izvršilnih funkcij, so vse bolj uporabljena metoda za zmanjšanje simptomov in $\mathrm{s}$ simptomi povezanih nevropsiholoških primanjkljajev pri otrocih z ADHD (Sonuga-Barke idr., 2014). Študije, ki vključujejo RKT za otroke z ADHD, uporabljajo različne metodološke pristope. $\mathrm{V}$ splošnem se tovrstne intervencije osredotočajo na kognitivne treninge $\mathrm{z}$ eno domeno (npr. delovni spomin), vendar pa študije kažejo, da imajo otroci z ADHD primanjkljaje na različnih področjih kognitivnega funkcioniranja, še posebej na področju izvršilnih sposobnosti. Izvršilne sposobnosti, na katerih se kažejo z motnjo povezani primanjkljaji, pa so vezane na različna možganska področja (Dovis idr., 2015). Dovis idr. zato menijo, da lahko trening, ki se nanaša na različne izvršilne sposobnosti, potencialno predstavlja najbolj učinkovito metodo pri zmanjšanju primanjkljajev na področju izvršilnih sposobnosti, ki se pojavljajo pri ADHD. ADHD je $\mathrm{z}$ vidika kognitivnih primanjkljajev zelo heterogena motnja. Intervencije, ki so bile uporabljene $\mathrm{v}$ preteklosti, so bile omejene na manjše število kognitivnih funkcij, kar je lahko povezano z manjšim obsegom pomembnih izboljšanj (Bikic idr., 2018).

\section{Raziskovalno vprašanje}

V pričujoči pregledni raziskavi smo poskušali na podlagi pregleda literature o vplivu RKT na različne vidike funkcioniranja otrok z ADHD strniti ugotovitve preteklih raziskav, pri čemer nas je zanimalo predvsem, katere vrste treninga so se do sedaj izkazale kot najbolj učinkovite in kateri dejavniki vplivajo na to, da je RKT učinkovit. Pri tem smo skušali odgovoriti na vprašanja, (a) kako učinkovit je RKT za izboljševanje funkcioniranja otrok z ADHD glede na uporabljene trenirane naloge, (b) kakšna je učinkovitost
RKT glede na trajanje treninga, (c) kako se učinkovitost RKT povezuje $\mathrm{z}$ motivacijo za reševanje treniranih nalog, (d) kakšna je učinkovitost RKT z vidika vpliva na vedenjske značilnosti otrok z ADHD, (e) kakšni so dolgoročni učinki RKT in (f) kakšna je učinkovitost RKT pri komorbidnih diagnozah. V prispevku smo kritično pregledali še pomanjkljivosti dosedanjih študij in podali predloge za nadaljnje študije na obravnavanem področju.

\section{Metoda}

Za namen prispevka smo pregledali vse podatkovne baze, vključene $\mathrm{v}$ zbirko EBSCOhost in baze Science Direct ter Web of Science. Članke smo iskali pod ključnimi besedami »računalniški kognitivni trening, ADHD, trening delovnega spomina in trening izvršilnih funkcij« $\mathrm{v}$ različnih kombinacijah. Po iskanju v podatkovnih bazah v vseh kombinacijah ključnih besed (vsaka kombinacija je vključevala ključno besedo ADHD) smo dobili skupno 1220 zadetkov. Po izključitvi podvojenih zadetkov smo na podlagi pregledanih naslovov in povzetkov $\mathrm{v}$ pregled literature vključili članke, ki so: (a) vključevali vzorec otrok z diagnozo ADHD ali ADHD s komorbidnimi diagnozami, izključili smo raziskave, ki so bile narejene na odraslih z motnjo ADHD in raziskave, ki niso vključevale udeležencev $\mathrm{z}$ diagnozo motnje ADHD; (b) za preučevanje učinka na funkcioniranje otrok z ADHD uporabili računalniško obliko kognitivnega treninga; (c) predstavljali raziskavo učinka RKT na omenjenem vzorcu in izključili študije primera. Pregledne znanstvene članke in metaanalize smo vključili v pregled, vendar jih nismo vključili v tabelo prikaza rezultatov pregleda (tabela 1). Skupaj smo v prispevek vključili 25 člankov, od tega dva znanstvena pregledna članka in dve metaanalizi. V pregled literature smo vključili članke, objavljene med letoma 2000 in 2020, ki so zadostili vključitvenim kriterijem.

$\mathrm{V}$ tabeli 1 so navedeni ključni podatki 21 raziskav na temo RKT za otroke z ADHD, ki smo jih vključili v pregled literature. Za vsako vključeno raziskavo smo $\mathrm{v}$ tabeli dodali opis kontrolne skupine, navedli smo trajanje RKT (dolžina in število treningov), vrsto RKT, v katerem okolju se je trening izvajal in morebitno prisotnost nagrajevanja udeležencev za izvajanje treninga. Za vsako vključeno raziskavo smo opisali vzorec udeležencev, pri čemer smo navedli število udeležencev, diagnozo in starost udeležencev. $\mathrm{V}$ tabeli 1 so navedeni ključni podatki o rezultatih raziskav, vključenih v pregled literature. Podatki, opisani v tabeli 1 vključujejo osebe, ki so bile vključene $\mathrm{v}$ ocenjevanje vedenjskih simptomov udeležencev, področja kognitivnega funkcioniranja udeležencev, ki so jih izmerili po opravljenem RKT, področja kognitivnega funkcioniranja, pri katerih se je pokazal statistično pomemben napredek, povezan z RKT in področja kognitivnega funkcioniranja, pri katerih se je pokazal statistično pomemben dolgoročni učinek RKT. Ob podatkih o statistično pomembnih napredkih, povezanih $\mathrm{z}$ RKT in dolgoročnih učinkih treninga so navedene velikosti učinka, ki jih navajajo avtorji. 


\section{Rezultati in razprava}

\section{Vrste RKT}

Študije, ki so preučevale RKT za otroke z ADHD, so pokazale različne rezultate oz. s treningom povezan napredek udeležencev, področja izboljšanja kognitivnega funkcioniranja in dolgoročni učinek treninga (glej tabelo 1). Eden izmed razlogov za razhajanja so zagotovo različne kognitivne sposobnosti, ki so jih RKT v raziskavah trenirali. Raziskave, vključene $\mathrm{v}$ pregled literature, so najpogosteje uporabljale RKT, ki je treniral eno izmed kognitivnih funkcij. Najpogosteje uporabljen je bil RKT delovnega spomina, opisan v 14 raziskavah, vključenih v pregled literature (Beck idr., 2010; Chacko idr., 2014; Egeland idr., 2013; Gray idr., 2012; Green idr., 2012; Hovik idr., 2013; Jones idr., 2020; Khalili Kermani idr., 2016; Klingberg idr., 2002, 2005; Mezzacappa in Buckner, 2010; Prins idr., 2011; van der Donk idr., 2015; van Dongen-Boomsma idr., 2014), v dveh vključenih raziskavah se je pojavljal tudi RKT pozornosti (Shalev idr., 2007; Steiner idr., 2011). Nekoliko manj raziskav (pet izmed vključenih v pregled literature) se je osredotočalo na RKT več različnih kognitivnih funkcij (multimodalni RKT; Bikic idr., 2018; Dovis idr., 2015; Johnstone idr., 2010, 2012; van der Oord idr., 2014).

$\mathrm{V}$ zgoraj navedenih raziskavah je bil med najpogosteje uporabljenimi in raziskanimi RKT za ADHD računalniški trening delovnega spomina Cogmed (angl. Cogmed working memory training - CWMT), ki razvija sposobnost vzdrževanja informacij v verbalnem in vidno-prostorskem delovnem spominu (Jones idr., 2020). Program temelji na formatu računalniške igre in prilagaja težavnost glede na uspešnost posameznikov (Chacko idr., 2014). Nekatere predhodne študije (npr. Beck idr., 2010; Chacko idr., 2014), ki so uporabljale CWMT, so pokazale, da se je pri otrocih z diagnozo ADHD s pomočjo treninga zmanjšalo število simptomov, povezanih z diagnozo. Beck idr. (2010) so preverjali učinek CWMT na funkcioniranje otrok in mladostnikov z ADHD in drugimi komorbidnimi diagnozami, in sicer na podlagi ocene funkcioniranja otroka s strani staršev. Ugotovili so, da so udeleženci izboljšali svoje sposobnosti ohranjanja pozornosti, načrtovanja in delovnega spomina, prav tako so starši po treningu ocenili, da je prišlo do pomembnega zmanjšanja števila simptomov ADHD (npr. težav na področju pozornosti in hiperaktivnost), pri čemer so avtorji ugotovili srednjo velikost učinka. Učinki treninga so se zadržali po štirih mesecih. Vendar pa rezultati niso pokazali pomembnega izboljšanja simptomov, ocenjenih s strani učiteljev.

Podobno so Klingberg idr. (2002) preučevali učinek CWMT na vzorcu otrok z ADHD, pri čemer so ugotovili, da je trening vplival na napredek na trenirani nalogi, prav tako pa so otroci napredovali na netrenirani nalogi delovnega spomina in izboljšali rezultat na Ravenovih progresivnih matricah, ki predstavlja neverbalni test kompleksnega mišljenja. Ob tem so avtorji izmerili tudi motorično aktivnost na podlagi pogostosti premikov glave med računalniškim testom in ugotovili, da se je motorična aktivnost pomembno zmanjšala v skupini, ki je bila vključena $\mathrm{v}$ trening delovnega spomina. Motorična aktivnost, izmerjena s tovrstno metodo, je $\mathrm{V}$ predhodnih raziskavah otrok $\mathrm{z}$ ADHD korelirala $\mathrm{z}$ vedenjskimi ocenami hiperaktivnosti (Teicher idr., 1996, citirano v: Klingberg idr., 2002).

Do podobnih rezultatov so Klingberg idr. (2005) prišli v kasnejši študiji učinka CWMT na različne kognitivne funkcije. Rezultati so pokazali, da so v primerjavi s kontrolno skupino udeleženci po koncu treninga statistično pomembno bolje reševali nalogo vidno-prostorskega delovnega spomina (trenirano nalogo), pri čemer se je pokazala velika velikost učinka, in naloge inhibicije in kompleksnega mišljenja (netrenirane naloge), pri katerih je bil učinek majhen. Učinki treninga so se zadržali tri mesece po končanem treningu. Pojavila se je tudi statistično pomembna sprememba v oceni s strani staršev v smeri zmanjšanja simptomov primanjkljajev na področju pozornosti in hiperaktivnosti oz. impulzivnosti (velika velikost učinka). Tudi pri starševski oceni se je pokazal dolgoročen učinek treninga.

Vendar pa nekatere raziskave, ki so uporabile podoben trening, niso ugotovile napredka na netreniranih nalogah. Chacko idr. (2014) so preučevali učinek CWMT na simptome motnje ADHD. Rezultati niso pokazali statistično pomembno večjega napredka pri eksperimentalni skupini z ADHD, vključeni v CWMT, v primerjavi s kontrolno skupino z ADHD (kontrolna skupina je bila t. i. placebo kontrolna skupina, saj so udeleženci sodelovali v podobnem treningu kot kontrolna skupina $\mathrm{z}$ vidika trajanja treninga in vrste treniranih nalog, vendar pa se težavnost ni prilagajala glede na posameznikovo uspešnost in je potekala na nižji ravni težavnosti). Skupini se nista razlikovali $\mathrm{v}$ ocenah simptomov ADHD s strani staršev in učiteljev, objektivnih merah pozornosti, aktivnosti in impulzivnosti, merah manipulacije s podatki verbalnega in neverbalnega delovnega spomina ter akademskih dosežkih. Udeleženci, vključeni v CWMT eksperimentalno skupino, so dosegli pomembno višje rezultate kot kontrolna skupina le pri nalogah verbalnega in neverbalnega delovnega spomina na ravni shranjevanja informacij. V nalogah delovnega spomina, pri katerih so udeleženci morali podatke tudi procesirati oziroma z njimi manipulirati, razlik med skupinama ni bilo. Prav tako ni bilo nobenih pomembnih razlik med skupinama v ocenah vedenja s strani staršev in učiteljev. Avtorji so na podlagi rezultatov zaključili, da je CWMT uporaben za namen izboljšanja nekaterih funkcij delovnega spomina, vendar nima pomembnega vpliva na simptome ADHD ali glavna področja funkcionalnih primanjkljajev.

Podobno tudi van der Donk idr. (2015) niso potrdili učinkov treninga s CWMT, ki so jih prepoznale predhodne študije. Edini pomemben napredek eksperimentalne skupine otrok z ADHD so prepoznali na področju vidno-prostorskega delovnega spomina (velika velikost učinka), medtem ko na področjih verbalnega delovnega spomina, pozornosti, ocene simptomov ADHD s strani staršev, izvršilnih sposobnosti in akademskih dosežkov ni bilo statistično pomembnih razlik med eksperimentalno in aktivno kontrolno skupino. Podobno so van Dongen-Boomsma idr. (2014) prepoznali pomemben učinek CWMT le na nalogo verbalnega delovnega spomina (majhna velikost učinka), ne pa na ocene vedenjskih simptomov motnje s strani staršev in učiteljev, vsakodnevnih izvršilnih sposobnosti in na mere globalnega kliničnega funkcioniranja otroka. 


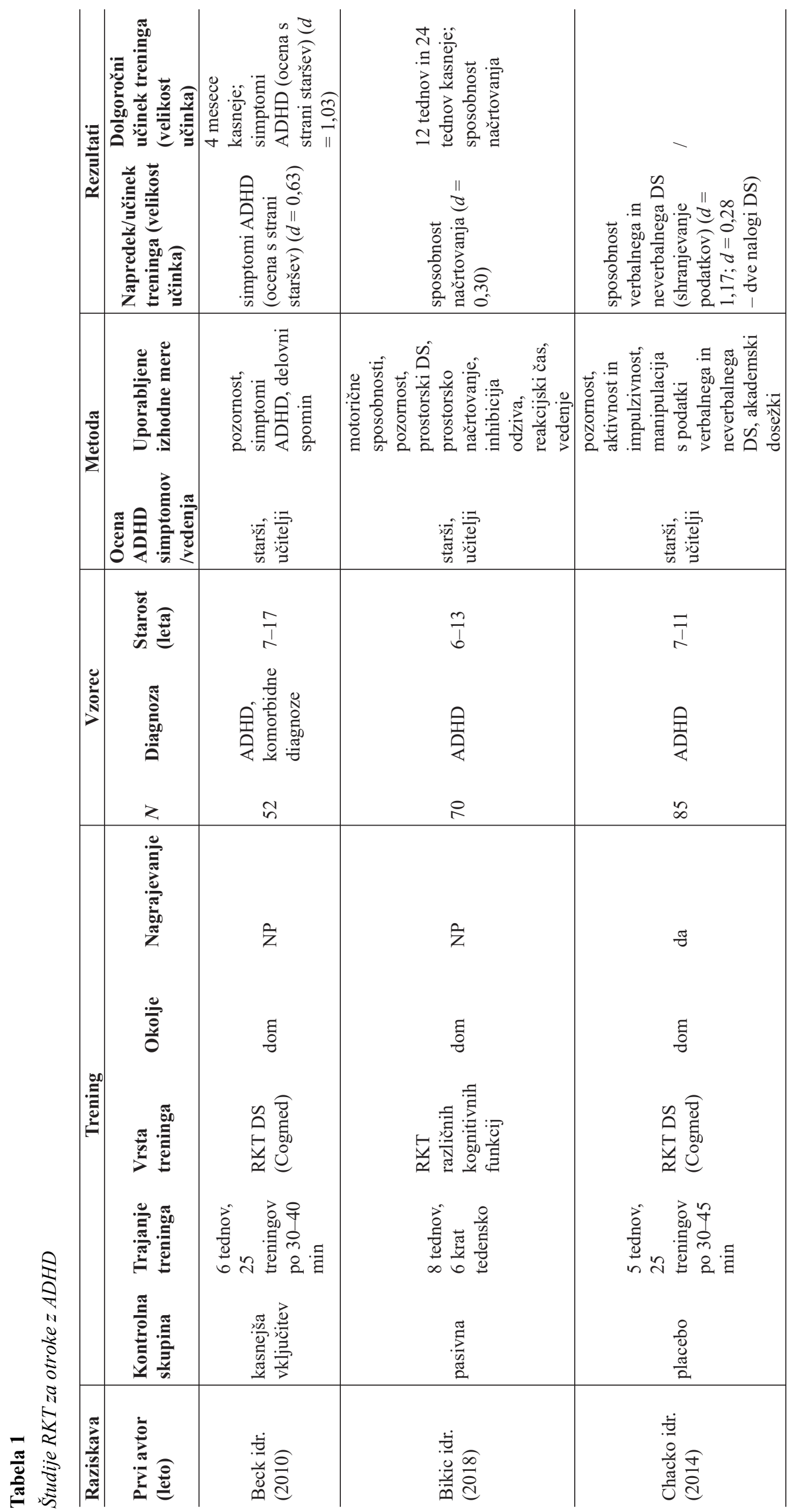




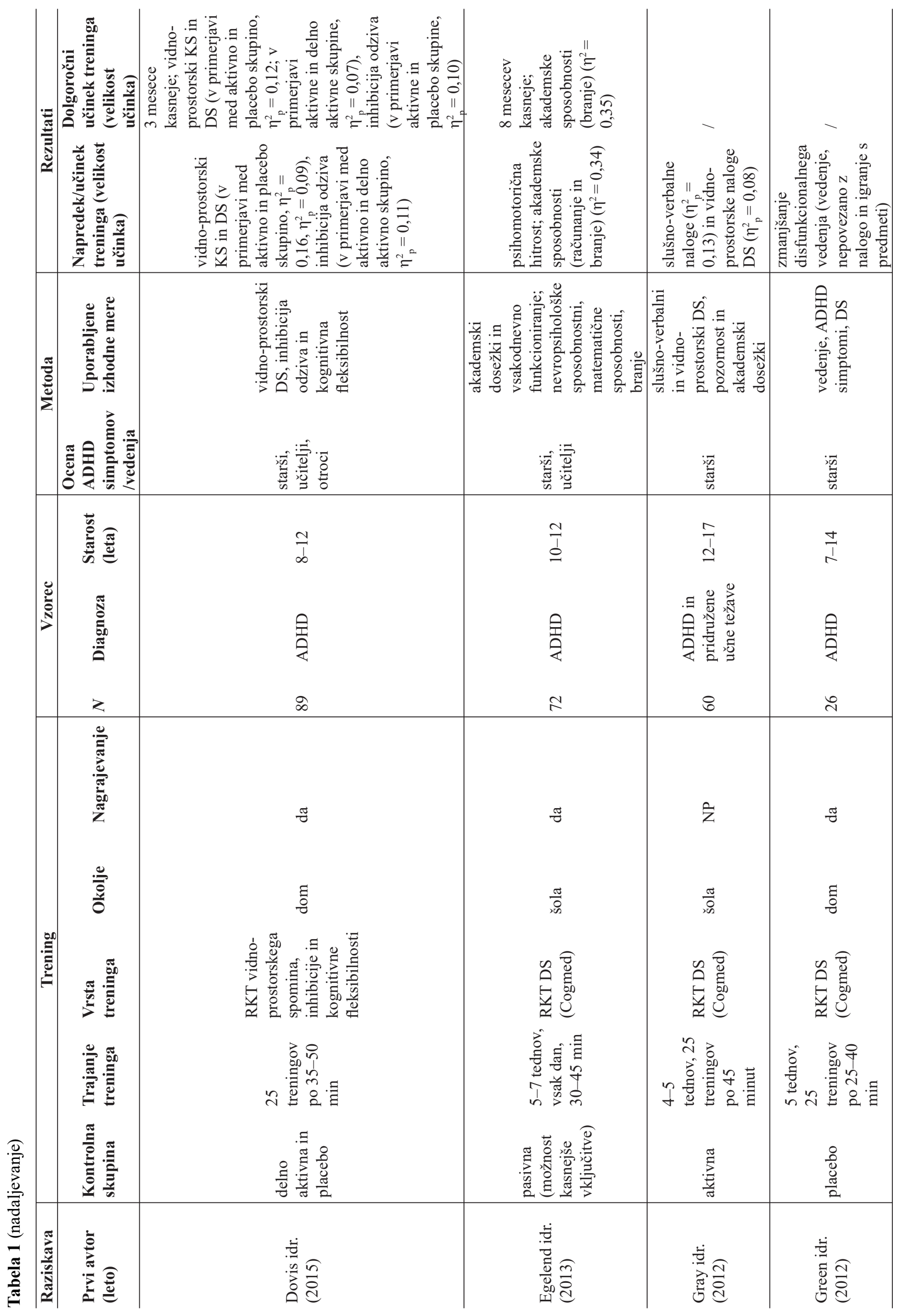




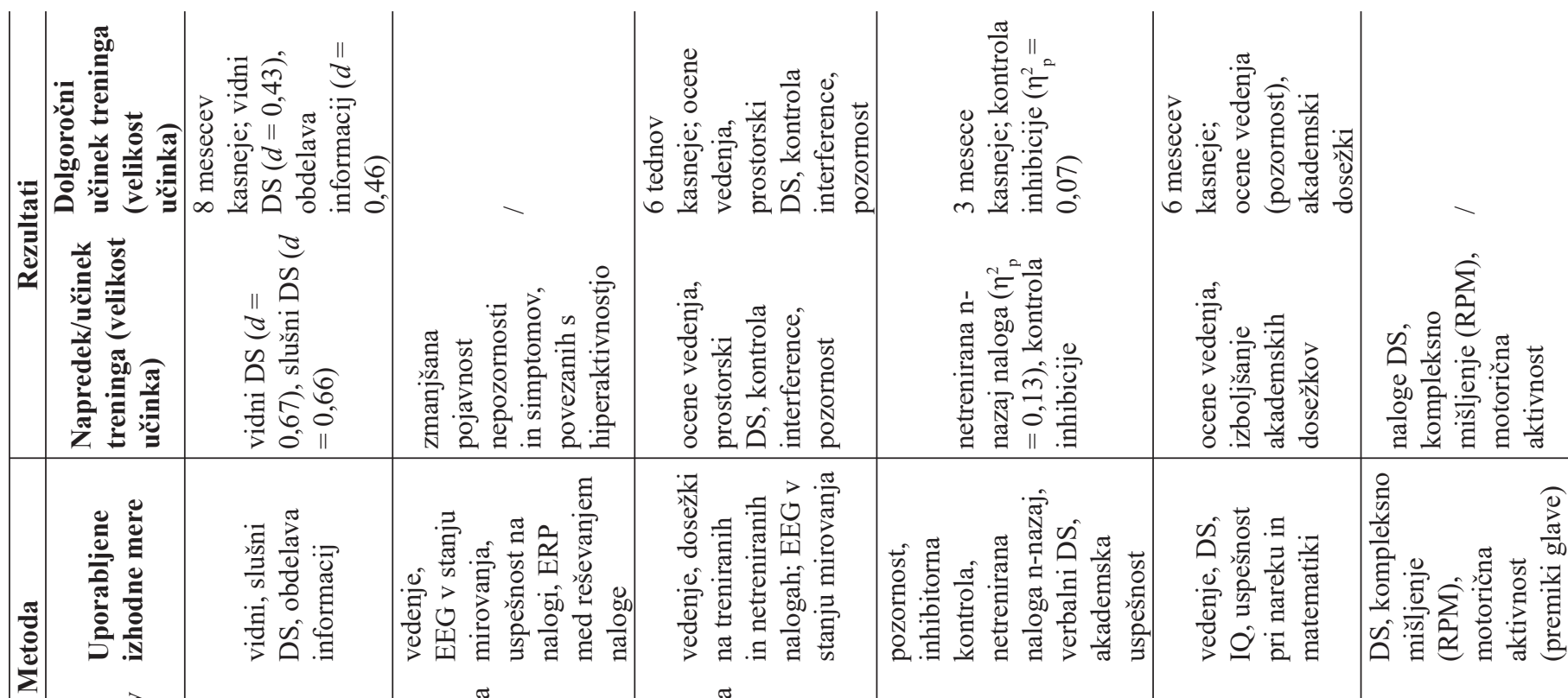
|

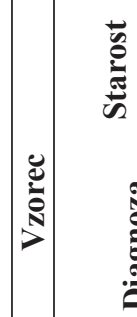

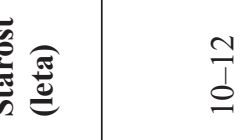

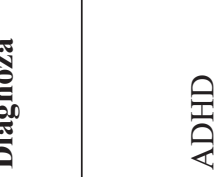

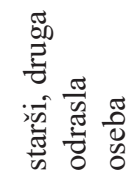

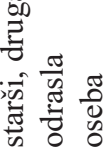

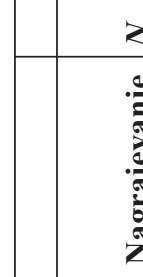

$2 \quad \hat{6}$

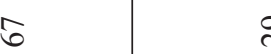

ते

$\stackrel{\infty}{\simeq} \quad \infty$

$\triangleright \quad 8$

8

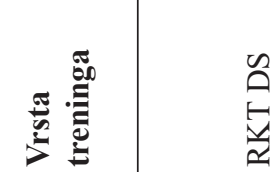

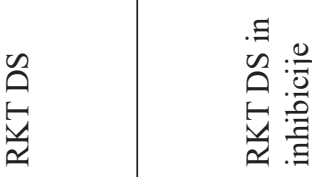

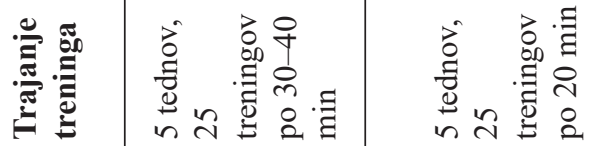

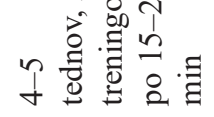

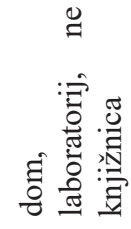

当

苟

高

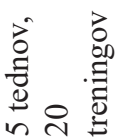

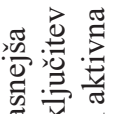
$\Xi \frac{\pi}{>} . \Xi$

붕

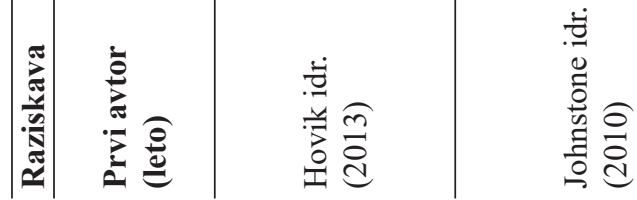

高的

\begin{tabular}{|c|c|c|}
\hline 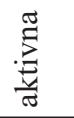 & 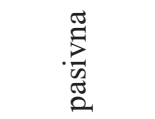 & $\begin{array}{l}\circ \\
\frac{0}{0} \\
\frac{\pi}{2}\end{array}$ \\
\hline & 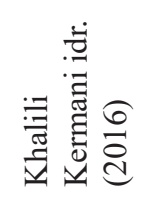 & 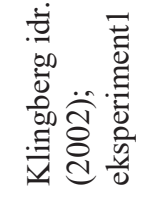 \\
\hline
\end{tabular}




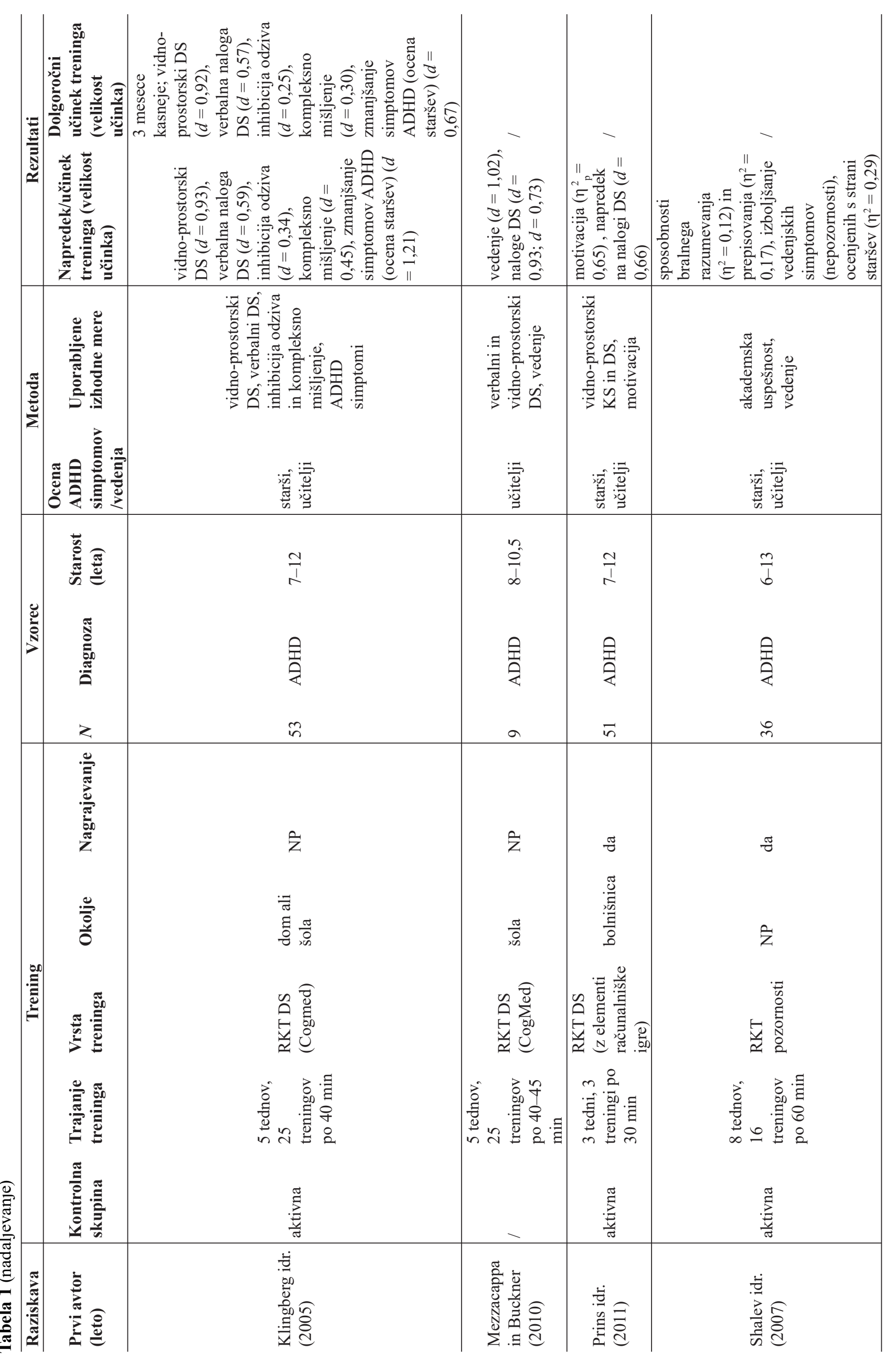




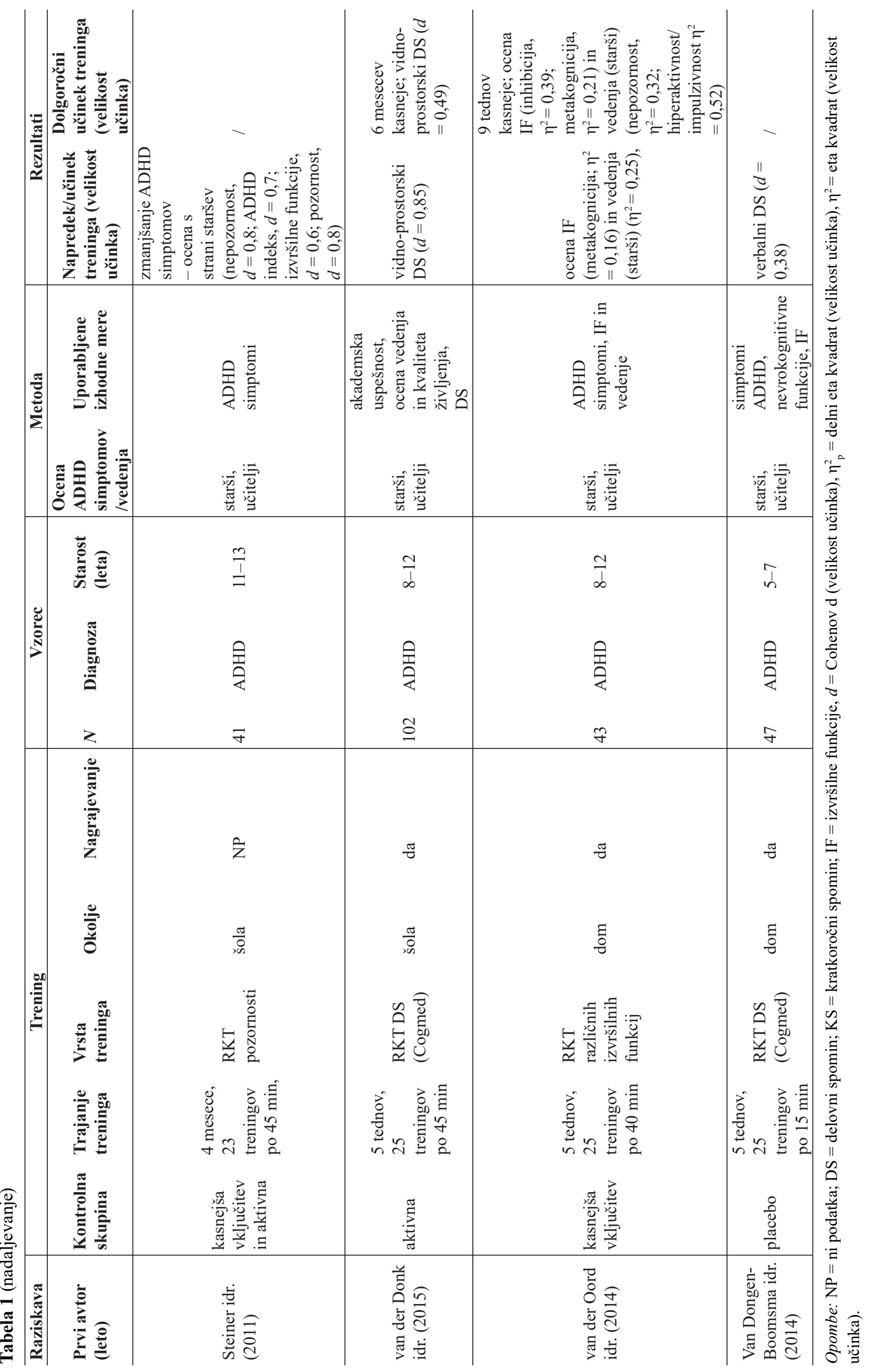


Shalev idr. (2007) so preverjali učinke RKT na izboljšanje sposobnosti ohranjanja pozornosti pri otrocih z ADHD. Program RKT, ki so ga uporabili, je sestavljen iz štirih setov strukturiranih nalog, ki so namenjeni treniranju sposobnosti ohranjanja pozornosti, selektivne pozornosti, usmerjanja pozornosti in izvršilne pozornosti. Program se prilagaja glede na uspešnost udeležencev. Udeleženci so statistično pomembno napredovali na netrenirani nalogi bralnega razumevanja in prepisovanja (majhna velikost učinka), prav tako pa so starši poročali o zmanjšanju simptomov ADHD, povezanih s pozornostjo (majhna velikost učinka). Steiner idr. (2011) so v pilotni študiji, v kateri so preverjali učinkovitost RKT pozornosti, ugotovili, da so starši otrok poročali o zmanjšanju intenzivnosti simptomov ADHD pri obeh skupinah, ki sta bili vključeni v kakršnokoli intervencijo, tj. eksperimentalni in aktivni kontrolni skupini (velikosti učinka za različne simptome ADHD so bile srednje do velike). Učitelji in učenci sami niso prepoznali nobenih pomembnih razlik $\mathrm{v}$ funkcioniranju pred in po treningu pozornosti.

Kljub predpostavkam, da so treningi, ki vključujejo več različnih kognitivnih funkcij, uspešnejši od tistih, ki vključujejo samo eno, nekatere raziskave te predpostavke ne potrjujejo. Med takšne študije multimodalnega RKT lahko uvrstimo študijo, ki so jo opravili Bikic idr. (2018), ki so preučevali učinek RKT različnih kognitivnih funkcij, kot so ohranjanje pozornosti, inhibicija odziva, kognitivna fleksibilnost, delovni spomin, prepoznavanje vzorcev in formiranje kategorij. Rezultati niso pokazali statistično pomembnega učinka na skorajda nobeno primarno ali sekundarno izhodno mero. Avtorji so zaključili, da ima intervencija učinek le na sposobnost načrtovanja (z majhno velikostjo učinka), in opazili izboljšanje na tem področju tudi dlje časa po zaključku treninga (po 12 in 24 tednih).

Po drugi strani so Dovis idr. (2015) preverjali učinek multimodalnega RKT na vidno-prostorski delovni spomin, inhibicijo in kognitivno fleksibilnost. Da bi bili udeleženci motivirani za opravljanje treninga, so jih avtorji nagrajevali (vse po enakem sistemu), in sicer so jim po zaključku posamezne igre dali $\mathrm{z}$ igro povezane nalepke, trakove in medalje. Pri otrocih, ki so bili vključeni v eksperimentalno skupino, se je pokazal napredek na nalogah vidnoprostorskega kratkoročnega spomina in delovnega spomina (majhna velikost učinka). Rezultati na področju inhibicije odziva in nadzora interference so se zvišali pri udeležencih $\mathrm{v}$ eksperimentalni skupini, prav tako pa pri delno aktivni kontrolni skupini (ki je trenirala inhibicijo in kognitivno fleksibilnost). Rezultati niso pokazali nobene razlike med skupinami na področju kognitivne fleksibilnosti, verbalnega delovnega spomina in kompleksnega mišljenja, prav tako ni bilo razlik med skupinami v ocenah vedenja s strani učiteljev, staršev in otrok, v merah izvršilnih sposobnosti motivacije ali starševskih ocenah problematičnega vedenja. Transfer na netrenirane naloge se je pojavil samo na področju nadzora interference, in sicer pri obeh treningih, ki sta vključevala naloge na področju izvršilnih sposobnosti. Rezultati so se zadržali tudi tri mesece po koncu treninga.

Vpliv multimodalnega RKT delovnega spomina in inhibicije odziva na otroke $\mathrm{z}$ ADHD so preučevali tudi Johnstone idr. (2010). Pred začetkom in ob koncu treninga so ocenili vedenje otrok, izmerili EEG v stanju mirovanja ter uspešnost na nalogi in $\mathrm{z}$ dogodkom povezan potencial (ERP; angl. event-related potential) med reševanjem naloge. Rezultati so pokazali, da se je pri otrocih, vključenih v RKT, zmanjšala pojavnost nepozornosti in simptomov, povezanih s hiperaktivnostjo, prav tako pa so se pri eksperimentalni skupini pojavile spremembe v možganskem valovanju v stanju mirovanja (povečana aktivnost $v$ delta valovanju in zmanjšana aktivnost $\mathrm{v}$ alfa in theta valovanju). $\mathrm{V}$ kasnejši študiji so Johnstone idr. (2012) preučevali učinke RKT delovnega spomina in inhibicije odziva na otrocih z ADHD. Izvedli so tudi ocenjevanje vedenja, izmerili dosežke na treniranih in netreniranih kognitivnih nalogah in EEG v stanju mirovanja. Pri ocenah vedenja otrok, ki so jih podali starši in druge odrasle osebe, so rezultati pokazali statistično pomembno večje izboljšanje pri otrocih z diagnozo ADHD, ki so bili vključeni v kateregakoli izmed treningov (eksperimentalni skupini in aktivni kontrolni skupini), kot pri udeležencih, ki niso bili vključeni v nobeno vrsto treninga. Prav tako so se pri otrocih z diagnozo ADHD pojavila izboljšanja, povezana s treningom, na področju prostorskega delovnega spomina, inhibicije motečih dražljajev in ohranjanja pozornosti. Napredki so se pri obeh skupinah ohranili šest tednov po zaključku treninga.

Cortese idr. (2015) so v metaanalizo zajeli različne vrste RKT in preučevali njihov učinek na simptome ADHD, nevropsihološke primanjkljaje in akademske sposobnosti (branje in računanje). Ugotovili so, da ima trening statistično pomembne učinke na simptome, povezane $\mathrm{z}$ zmanjšano pozornostjo, na dosežke delovnega spomina in ocene izvršilnih sposobnosti s strani staršev. Učinki treninga na simptome hiperaktivnosti in impulzivnosti niso bili statistično pomembni. Prav tako niso bili statistično pomembni učinki na akademske dosežke. Avtorji so zaključili, da ima, kljub izboljšanju izvedbe na treniranih nalogah delovnega spomina, kognitivni trening le omejen vpliv na simptome ADHD. Večji učinek na simptome ADHD ima sicer, glede na rezultate metaanalize, multimodalni trening. Cortese idr. ugotavljajo, da pristopi, ki vključujejo več različnih nevropsiholoških procesov, bolje optimizirajo transfer učinkov od kognitivnih sprememb na zmanjšanje kliničnih simptomov.

\section{Trajanje RKT}

Eden izmed dejavnikov, ki vplivajo na uspešnost RKT, je najverjetneje tudi trajanje kognitivnega treninga. Nekatere študije (Chacko idr., 2014; Dovis idr., 2015; Green idr., 2012; Hovik idr., 2013; Johnstone idr., 2010; Jones idr., 2020; Klingberg idr., 2002, 2005; Mezzacappa in Buckner, 2010; van der Donk idr., 2015; van der Oord idr., 2014; van DongenBoomsma idr., 2014) so pri uporabi pet tednov trajajočega kognitivnega treninga prišle do različnih rezultatov. Medtem ko so Chacko idr. (2014), Dovis idr. (2015) in Green idr. (2012) ugotovili napredek le na nekaterih izmed izhodnih mer, so npr. Klingberg idr. (2005) ter Mezzacappa in Buckner (2010) poročali o napredku na vseh izmerjenih izhodnih merah (glej tabelo 1). Bikic idr. (2018) so uporabili dlje časa trajajoč trening $\mathrm{s}$ pričakovanjem, da bo večja količina treningov 
prinesla večji napredek udeležencev, vendar te predpostavke na podlagi rezultatov treninga niso uspeli potrditi. Menijo, da je morda izboljšanje celo bolj verjetno pri nekoliko krajšem treningu, saj predstavlja manjšo obremenitev za otroke in njihove družine.

Klingberg (2010) predpostavlja, da je daljši trening (vsaj 8 ur) pogoj za uspešnost treninga delovnega spomina. Po drugi strani pa so Prins idr. (2011) v raziskavi prepoznali pozitivne učinke RKT, ki temelji na principu računalniške igre, le po treh 30-minutnih treningih $\mathrm{v}$ časovnem obdobju treh tednov. Preostale raziskave, vključene v pregled literature, so poročale o časovnem obdobju RKT med pet tednov in štirimi meseci. Prins idr. (2011) ugotavljajo, da lahko manjše število treningov v obliki računalniške igre privede do podobnega napredka kot večje število treningov drugega formata. Uspešnost kognitivnega treninga lahko torej najverjetneje povežemo $\mathrm{z}$ motiviranostjo udeležencev za opravljanje treninga.

\section{Motivacija za opravljanje nalog RKT pri otrocih z ADHD}

Težave na področju motivacije lahko zmanjšajo uspešnost kognitivnega treninga (Prins idr., 2011). Trening izvršilnih sposobnosti v obliki računalniške video igre predstavlja možnost za višanje motivacije in učinkov treninga pri otrocih z ADHD (Dovis idr., 2012). Kühn idr. (2011) to pojasnjujejo $\mathrm{s}$ tem, da igranje iger dviguje raven sproščanja dopamina $\mathrm{v}$ striatalnih možganih, kar poviša dolgoročno potenciacijo nevralnih povezav $\mathrm{v}$ striatumu in vpliva na povečanje motivacije in zmožnosti učenja.

Najpogostejši RKT za otroke $\mathrm{z}$ motnjo pozornosti uporabljajo postopke, s katerimi avtomatsko prilagodijo težavnost naloge, da bi nenehno stimulirali udeleženca, da doseže meje svojih sposobnosti (Cortese idr., 2015). Prilagajanje težavnosti vpliva na motivacijo udeležencev, saj onemogoča znižanje motivacije zaradi prevelike težavnosti naloge in posledičnega občutka frustracije ob njenem reševanju, prav tako pa preprečuje zmanjšanje motivacije ob reševanju naloge, ki je za udeleženca preveč enostavna.

Van der Oord idr. (2014) ugotavljajo, da je visoko intenzivno ojačanje $\mathrm{v}$ obliki nagrajevanja učinkovitejše pri izboljšanju izvedbe na nalogah pri otrocih z ADHD v primerjavi z otroki brez diagnoze ADHD. Otroci z ADHD imajo raje takojšnjo nagrado kot odloženo. Ker so ojačitve $\mathrm{v}$ obliki nagrajevanja $\mathrm{v}$ veliki meri povezane $\mathrm{z}$ ravnjo motivacije, raziskave predpostavljajo, da nizka raven notranje motivacije vpliva na slabšo izvedbo pri otrocih z diagnozo ADHD. Van der Oord idr. menijo, da je rešitev za izboljšanje motivacije za izvedbo RKT pri otrocih dodajanje elementov računalniške igre v naloge za trening. Prav tako tudi Prins idr. (2011) ugotavljajo, da otroci z ADHD kažejo višjo motivacijo za naloge izvršilnih sposobnosti z elementi računalniške igre kot za naloge izvršilnih sposobnosti brez takih elementov. Pri nalogi z elementi računalniške igre vztrajajo dlje časa, tudi brez nadzora odrasle osebe.

\section{Vpliv RKT na vedenje pri otrocih z ADHD}

Razhajanja pri učinkih RKT se pojavljajo tudi na področju ocen neprilagojenega vedenja otrok z ADHD, ki predstavlja pogost simptom motnje (Rapport idr., 2013; Rutledge idr., 2012). Kljub temu da je konstrukt ADHD postal vse bolj povezan s kognicijo (premik od vedenjske »hiperkinetične« terminologije), diagnoza ADHD še vedno temelji na opažanjih na področju vedenja in sklepanja o procesih, ki vplivajo na vedenje (Manly idr., 2001).

Nekateri avtorji so tako želeli preveriti, ali lahko RKT vplivajo na vedenje otrok z ADHD (Green idr, 2012; Johnstone idr., 2010, 2012; Khalili Kermani idr., 2016; Shalev idr., 2007; van der Donk idr., 2015; van der Oord idr., 2014). Green idr. (2012) so npr. v raziskavi preučevali učinek RKT delovnega spomina pri otrocih z ADHD na disfunkcionalne vedenjske vzorce, povezane z motnjo. Preverili so učinek treninga na vedenjske značilnosti udeležencev, ADHD simptome in sposobnosti delovnega spomina. Trening delovnega spomina je pripomogel $\mathrm{k}$ pomembnemu zmanjšanju z ADHD povezanega disfunkcionalnega vedenja, kar so avtorji ocenjevali s pomočjo opazovanja odkrenljivosti od zastavljene naloge (usmerjanje pogleda stran od naloge) in opazovanjem igranja s predmeti, ki niso del naloge. Prav tako so se izboljšale sposobnosti na nalogah delovnega spomina. Vendar pa rezultati niso pokazali nobenih statistično pomembnih izboljšanj v ocenah vedenja s strani staršev udeležencev.

\section{Dolgoročni učinek treninga}

Hovikidr. (2013) so v raziskavi preverjali dolgoročni učinek RKT delovnega spomina na standardne naloge delovnega spomina pri otrocih z ADHD. Udeležence so testirali na področju vidnega, slušnega delovnega spomina in na področju obdelave informacij, shranjenih $\mathrm{v}$ delovnem spominu, en teden pred začetkom intervencije, takoj po zaključku intervencije in osem mesecev kasneje. $\mathrm{V}$ primerjavi s pasivno kontrolno skupino se je pri eksperimentalni skupini pojavil dolgoročni učinek na vseh merjenih področjih, pri čemer so izračunali srednje velikosti učinka. Avtorji so zaključili, da je sistematičen trening pripomogel $\mathrm{k}$ dolgoročnemu napredku na nalogah, ki so bile podobne nalogi $\mathrm{v}$ treningu. Podobni rezultati so se pojavili v številnih študijah, ki so preučevale dolgoročni učinek RKT (Beck idr., 2010; Bikic idr., 2018; Dovis idr., 2015; Hovik idr., 2013; Johnstone idr., 2012; Khalili Kermani idr., 2016; Klingberg idr., 2005; van der Donk idr., 2015; van der Oord idr., 2014), medtem ko nekateri avtorji opisujejo le delni dolgoročni učinek RKT, kar pomeni, da se je dolgoročni učinek RKT pojavil le na eni izmed izhodnih mer (Egelend idr., 2013; Jones idr., 2020).

\section{Sopojavnost z drugimi motnjami in učinek RKT}

Raziskave kažejo, da naj bi RKT pozitivno vplival na uspešnost pri premagovanju nekaterih primanjkljajev, ki se pojavljajo pri otrocih z ADHD (Beck idr., 2010; Bikic idr., 
2018; Chacko idr., 2014; Dovis idr., 2015; Green idr., 2012; Hovik idr., 2013; Johnstone idr., 2010, 2012; Jones idr., 2020; Klingberg idr., 2002, 2005; Mezzacappa in Buckner, 2010; Prins idr., 2011; Shalev idr., 2007; Steiner idr., 2011; van der Donk idr., 2015; van der Oord idr., 2014; van Dongen-Boomsma idr., 2014), vendar pa ni veliko raziskav, ki bi preverjale, ali so treningi učinkoviti tudi za otroke s pridruženimi komorbidnimi diagnozami. Kljub pogostemu pojavljanju komorbidnosti in neugodnim posledicam za otrokov akademski in psihosocialni razvoj, ni veliko raziskav, ki bi preučevale intervencije, namenjene posameznikom $\mathrm{z}$ ADHD in pridruženimi SUT (Hudoklin in Magajna, 2019).

Gray idr. (2012) so na vzorcu 60 mladostnikov, starih med 12 in 17 let ter z motnjo pozornosti s hiperaktivnostjo in pridruženimi učnimi težavami, preverjali učinek CWMT in matematičnega treninga na sposobnosti slušno-verbalnega in vidno-prostorskega spomina. Preverjali so tudi bližnji in daljni transfer na pozornost in akademske dosežke. Rezultati so pokazali, da so $\mathrm{v}$ primerjavi z udeleženci matematičnega treninga udeleženci po treningu delovnega spomina izboljšali dosežke na nalogah delovnega spomina (majhna velikost učinka), vendar se napredki na treningu niso prenesli na druge mere kognitivnega funkcioniranja. Avtorji so tako zaključili, da lahko otroci in mladostniki z ADHD in pridruženimi učnimi težavami napredujejo s pomočjo treninga delovnega spomina, vendar pa se pri tem ne pojavi transfer na netrenirana področja (npr. pozornost in akademske dosežke).

Egeland idr. (2013) pa so ugotovili, da lahko RKT delovnega spomina vpliva tudi na akademske dosežke. Preučevali so učinek RKT na nevropsihološke domene, akademske dosežke in vsakodnevno funkcioniranje doma in v šoli. V raziskavo so vključili 67 otrok z ADHD, pri čemer so udeležence pred treningom, po treningu in osem mesecev po zaključku treninga ocenili na področju nevropsiholoških sposobnosti, matematičnih sposobnosti, branja in ocenjevalnih lestvic, ki so jih izpolnili starši in učitelji. Rezultati so pokazali statistično pomemben učinek treninga na psihomotorično hitrost, ne pa na druge mere nevropsihološkega funkcioniranja. Pri udeležencih $\mathrm{v}$ eksperimentalni skupini pa so se izboljšale sposobnosti računanja in branja, pri čemer se je pri branju pojavil dolgoročni napredek (po osmih mesecih), povezan s treningom. Rezultati pa niso pokazali nobenih izboljšanj, opaženih s strani staršev in učiteljev.

\section{Zaključek in predlogi za nadaljnje raziskave}

Raziskave na področju RKT za otroke z ADHD kažejo, da tovrstni treningi vplivajo na izboljšanje nekaterih kognitivnih sposobnosti, kot so sposobnost načrtovanja (Bikic idr., 2018), delovni spomin (Chacko idr., 2014; Gray idr., 2012; Hovik idr., 2013; Johnstone idr., 2012; Klingberg idr., 2002, 2005, Mezzacappa in Buckner, 2010; Prins idr., 2011; van der Donk idr., 2015; van Dongen-Boomsma idr., 2014), kratkoročni spomin (Dovis idr., 2015), nadzor interference (Dovis idr., 2015; Johnstone idr., 2012), psihomotorična hitrost (Egeland idr., 2013). Hkrati pa kažejo tudi pozitiven učinek na spretnosti, ki so vezane na akademske sposobnosti (Egeland idr., 2013; Khalili Kermani idr., 2016; Shalev idr., 2007), in vpliv na zmanjšanje pojavljanja simptomov ADHD
(Beck idr., 2010; Dovis idr., 2015; Green idr., 2012; Johnstone idr., 2010, 2012; Khalili Kermani idr., 2016; Klingberg idr., 2005; Shalev idr., 2007; Steiner idr., 2011; van der Oord idr., 2014). Nekatere raziskave so uspele potrditi učinek RKT le na nekaterih področjih kognitivnega funkcioniranja ali niso uspele potrditi učinka v vseh izhodnih merah, v katerih so avtorji napredek, povezan z RKT, pričakovali.

Nekateri avtorji predpostavljajo, da je med najbolj učinkovitimi RKT multimodalni trening (Cortese idr., 2015), saj potencialno vpliva na različne kognitivne funkcije, pri čemer se poveča možnost za daljni transfer. Rezultati večine predhodnih raziskav, ki so uporabljale multimodalni RKT, kažejo na uspešnost na področju transfera na netrenirana področja in dolgoročnega učinka treninga (Bikic idr., 2018; Dovis idr., 2015; Johnstone idr., 2010, 2012; van der Oord idr., 2014). Med pomembne dejavnike za uspešnost RKT spada tudi trajanje treninga, vendar pa raziskave kažejo, da dlje časa trajajoči treningi niso nujno uspešnejši od krajših treningov. Prins idr. (2011) na primer ugotavljajo, da se lahko pozitiven učinek treninga pokaže že pri krajšem treningu, vendar predpostavljajo, da pri tem pomembno vlogo igra motivacija posameznika za opravljanje treninga. RKT, ki vsebujejo komponente računalniške video igre, naj bi vplivali na povečanje motivacije in $\mathrm{s}$ tem izboljšali možnost napredka pri otrocih z ADHD (Dovis idr., 2012).

Glede na dosedanje raziskave ni povsem jasno, ali je najboljša strategija za treniranje kognitivnih sposobnosti prav multimodalni RKT. Nekateri avtorji (Bikic idr., 2018; van der Oord idr., 2014) sicer predpostavljajo, da je sočasno treniranje več različnih izvršilnih sposobnosti bolj učinkovito (še posebej za prenos učinkov na vsakdanje življenje) kot pa treniranje enega tipa izvršilne sposobnosti v posameznem treningu (treniranje vsake izvršilne sposobnosti v ločenih treningih), saj tudi funkcioniranje $\mathrm{v}$ vsakdanjem življenju zahteva uporabo različnih izvršilnih sposobnosti hkrati. Vendar pa Dovis idr. (2015) v raziskavi ugotavljajo, da treniranje treh različnih izvršilnih sposobnosti znotraj enega treninga nima večjega učinka na vsakodnevno funkcioniranje kot treniranje dveh različnih izvršilnih sposobnosti. Cortese idr. (2015) v metaanalizi po drugi strani ugotavljajo, da raziskave, ki vključujejo več različnih nevropsiholoških procesov, v večji meri omogočajo transfer učinkov treninga kognitivnih sposobnosti na izboljšanje na področju kliničnih simptomov in primanjkljajev, ki so značilni za otroke $\mathrm{z}$ ADHD, vendar pa v metaanalizo niso vključili zadostnega števila raziskav, ki vključujejo multimodalni trening, da bi lahko predpostavko z gotovostjo potrdili. Predvidevajo, da obstaja možnost, da se multimodalni treningi izkazujejo kot uspešnejši tudi zaradi s tem pogosto povezanega večjega števila treningov (Cortese idr., 2015). V prihodnje bi bilo torej smiselno natančneje preučiti RKT, ki vključujejo več različnih kognitivnih sposobnosti, saj to področje še ni dovolj raziskano, da bi lahko izpeljali ustrezne zaključke.

Na podlagi predhodnih raziskav torej lahko do neke mere sklepamo o dejavnikih, ki vplivajo na uspešnost RKT pri otrocih z ADHD. Pri oblikovanju RKT za otroke z ADHD je treba upoštevati heterogenost skupine otrok s tovrstno motnjo in različno izražene primanjkljaje na različnih področjih. Obstoječe študije namreč večinoma ne prilagajajo intervencij 
obstoječim kognitivnim primanjkljajem udeležencev $\mathrm{v}$ raziskavi. Na področju študij na populaciji otrok z ADHD se pojavlja praksa vključevanja otrok $\mathrm{z}$ omenjeno motnjo, ne glede na njihove individualne primanjkljaje na začetku izvajanja treninga. Predpostavlja se, da imajo posamezniki $\mathrm{z}$ motnjo pozornosti s hiperaktivnostjo enake potrebe, zato se pogosto pričakuje, da bodo po intervenciji pridobili enako (Bikic idr., 2018). Če ima posameznik z motnjo pozornosti s hiperaktivnostjo težave predvsem na področju pozornosti in nima težav na področju delovnega spomina, je manj smiselno trenirati delovni spomin in pričakovati, da se bo učinek treninga generaliziral na področje pozornosti (Bikic idr., 2018). Glede na to, da je motnja pozornosti s hiperaktivnostjo izredno heterogena motnja na individualnem nivoju, Bikic idr. predlagajo, da se prihodnje študije z večjimi vzorci lotijo ločevanja udeležencev na podskupine. $\mathrm{V}$ prihodnje bi morali biti pristopi zasnovani na podlagi potreb posameznikovega kognitivnega profila (Bikic idr., 2018). Druga težava pri raziskavah RKT za otroke z ADHD ali ADD je tudi ta, da je težko najti primerno kontrolno skupino. Optimalna kontrolna skupina $\mathrm{v}$ študiji, ki vključuje kognitivni trening, bi bila aktivna placebo skupina, ki bi izvajala intervencijo, ki nima učinka na kognicijo (Bikic, 2018), vendar bi morali obe skupini za trening uporabljati iste ali pa vsaj podobne naloge, kar lahko predstavlja velik izziv za raziskovalce.

Nadaljnje raziskave so potrebne tudi za potrditev hipoteze, da RKT vplivajo na dolgoročno izboljšanje izvršilnih sposobnosti pri otrocih s primanjkljaji na tem področju. Pomemben učinek tovrstnih treningov je izboljšanje vsakodnevnega delovanja otrok, na primer izboljšanje na področju organizacijskih veščin, lažje razumevanje navodil, lažje pomnjenje pri učenju, izboljšanje akademske uspešnosti, zmanjšanje težav na področju medosebnih odnosov itd. Prav tako bi bilo $\mathrm{v}$ prihodnjih raziskavah smiselno preveriti, kakšen učinek ima nagrajevanje udeležencev na učinek RKT. Dovis idr. (2012) so namreč v raziskavi ugotovili, da je manjši učinek treninga lahko pri otrocih z ADHD v veliki meri povezan s primanjkljaji na področju motivacije in da učinkovitost izvedbe po daljšem času ostaja stabilna samo v primeru konstantne in večje spodbude. Prav tako raziskave kažejo, da so RKT, ki uporabljajo obliko računalniške igre, lahko bolj uspešni kot ostale vrste treningov, kar povezujejo predvsem z ravnjo motivacije za vztrajanje pri aktivnosti (Prins idr., 2011; Dovis idr., 2012).

Raziskav, ki bi preverjale učinkovitost RKT za otroke s komorbidnimi diagnozami, ni veliko. Zaradi pogostosti in neugodnih posledic, ki so vezane na sopojavnost ADHD z drugimi diagnozami (kot npr. SUT), bi bilo smiselno to področje podrobneje raziskati. Kljub temu, da so avtorji raziskave, $\mathrm{v}$ kateri so preverjali učinek RKT na otroke z diagnozo ADHD in SUT, ugotovili, da se pri otrocih s komorbidno diagnozo kaže pomanjkanje transfera na netrenirana področja (Gray idr., 2012), pa raziskava Egelanda idr. (2013) kaže, da ima v raziskavah uporabljen RKT delovnega spomina potencial za izboljšanje sposobnosti, ki so vezane na učno uspešnost (kot sta branje in pisanje).

Dosedanje študije RKT za otroke z ADHD kažejo nekatere zelo obetavne rezultate in potrjujejo pomemben vpliv na izboljšanje nekaterih kognitivnih in vedenjskih značilnosti in primanjkljajev, ki so vezani na ADHD. Vendar pa so rezultati študij kljub temu precej nekonsistentni, zaradi česar je potrebnih več raziskav, preden bi lahko bil kognitivni trening uveljavljen kot eden izmed učinkovitih načinov odpravljanja oziroma zmanjševanja simptomov motnje pozornosti $\mathrm{s}$ hiperaktivnostjo.

\section{Literatura}

Astle, D. E. in Scerif, G. (2011). Interactions between attention and visual short-term memory (VSTM): What can be learnt from individual and developmental differences? Neuropsychologia, 49, 1435-1445.

Baddeley, A. (2000). The episodic buffer: A new component of working memory? Trends in Cognitive Sciences, 4(11), 417-423.

Baddeley, A. D. in Hitch, G. (1974). Working memory. Psychology of Learning and Motivation, 8, 47-89.

Baltes, P. B. (1987). Theoretical propositions of life-span developmental psychology: On the dynamics of growth and decline. Developmental Psychology, 23(5), 611-626.

Barkley, R. A. (2018). Attention-deficit hyperactivity disorder: A Handbook for diagnosis \& treatment (4. izd.). The Guilford Press.

Beck, S. J., Hanson, C. A., Puffenberger, S. S., Benninger, K. L. in Benninger, W. B. (2010). A controlled trial of working memory training for children and adolescents with ADHD. Journal of Clinical Child \& Adolescent Psychology, 39(6), 825-836.

Biederman, J., Monuteaux, M. C., Doyle, A. E., Seidman, L. J., Wilens, T. E., Ferrero, F., Morgan, C. L. in Faraone, S. V. (2004). Impact of executive function deficits and attention-deficit/hyperactivity disorder (ADHD) on academic outcomes in children. Journal of Consulting and Clinical Psychology, 72(5), 757-766.

Bikic, A., Leckman, J. F., Christensen, T. Ø., Bilenberg, N. in Dalsgaard, S. (2018). Attention and executive functions computer training for attention-deficit/hyperactivity disorder (ADHD): Results from a randomized, controlled trial. European Child \& Adolescent Psychiatry, 27(12), 1563-1574.

Borella, E., Carretti, B., Riboldi, F. in De Beni, R. (2010). Working memory training in older adults: Evidence of transfer and maintenance effects. Psychology and Aging, 25(4), 767-778.

Burgess, G. C., Depue, B. E., Ruzic, L., Willcutt, E. G., Du, Y. P. in Banich, M. T. (2010). Attentional control activation relates to working memory in attentiondeficit/hyperactivity disorder. Biological Psychiatry, 67(7), 632-640.

Chacko, A., Bedard, A. C., Marks, D. J., Feirsen N., Uderman, J. Z., Chimiklis, A., Rajwan, E., Cornwell, M., Anderson, L., Zwilling, A. in Ramon, M. (2014). A randomized clinical trial of Cogmed Working Memory Training in school-age children with ADHD: A replication in a diverse sample using a control condition. Journal of Child Psychology and Psychiatry, 55(3), 247-255. 
Cortese, S., Ferrin, M., Brandeis, D., Buitelaar, J., Daley, D., Dittmann, R. W., Holtmann, M., Santosh, P., Stevenson, J., Stringaris, A., Zuddas, A. in SonugaBarke, E. J. S. (2015). Cognitive training for attentiondeficit/hyperactivity disorder: Meta-analysis of clinical and neuropsychological outcomes from randomized controlled trials. Journal of the American Academy of Child \& Adolescent Psychiatry, 54(3), 164-174.

Dovis, S., Van der Oord, S., Wiers, R. W. in Prins, P. J. M. (2012). Can motivation normalize working memory and task persistence in children with attentiondeficit/hyperactivity disorder? The effects of money and computer-gaming. Journal of Abnormal Child Psychology, 40(5), 669-681.

Dovis, S., Van der Oord, S., Wiers, R. W. in Prins, P. J. M. (2015). Improving executive functioning in children with ADHD: Training multiple executive functions within the context of a computer game. A randomized doubleblind placebo controlled trial. PLoS One, 10(4), članek e0121651.

Durston, S., van Belle, J. in de Zeeuw, P. (2011). Differentiating frontostriatal and fronto-cerebellar circuits in attentiondeficit/hyperactivity disorder. Biological Psychiatry, 69(12), 1178-1184.

Egeland, J., Aarlien, A. K. in Saunes, B. K. (2013). Few effects of far transfer of working memory training in ADHD: A randomized controlled trial. PLoS One, 8(10), članek e75660.

Forslund, T., Brocki, K., Bohlin, G., Granqvist P. in Eninger, L. (2016). The heterogeneity of attention deficit/ hyperactivity disorder symptoms and conduct problems: Cognitive inhibition, emotional regulation, emotionality, and disorganized attachment. British Journal of Developmental Psychology, 34(3), 371-387.

Gray, S. A., Chaban, P., Martinussen, R., Goldberg, R., Gotlieb, H., Kronitz, R., Hockenberry, M. in Tannock, R. (2012). Effects of a computerized working memory training program on working memory, attention, and academics in adolescents with severe LD and comorbid ADHD: A randomized controlled trial. Journal of Child Psychology and Psychiatry, 53(12), 1277-1284.

Green, C. T., Long, D. L., Green, D., Iosif, A. M., Dixon, J. F., Miller, M. R., Fassbender, C. in Schweitzer, J. B. (2012). Will working memory training generalize to improve off-task behavior in children with attentiondeficit/hyperactivity disorder? Neurotherapeutics, 9(3), 639-648.

Hovik, K. T., Saunes, B. K., Aarlien, A. K. in Egeland, J. (2013). RCT of working memory training in ADHD: Long-term near-transfer effects. PLoS One, 8(12), članek e80561.

Hudoklin, M. in Magajna, L. (2019). Kognitivni in psihosocialni profili učencev s specifičnimi motnjami učenja (SUT), motnjo aktivnosti in pozornosti (ADHD) in sopojavljanjem SUT in ADHD [Cognitive and psychosocial profiles of pupils with specific learning disabilities, attention deficit/hyperactivity disorder, and their comorbidity]. V P. Janjušević (ur.), Komorbidnost psihosocialnih motenj pri otrocih in mladostnikih [Comorbidity of psychosocial disorders in children and adolescents] (str. 36-50). Svetovalni center za otroke, mladostnike in starše Ljubljana.
Jakobson, A. in Kikas, E. (2007). Cognitive functioning in children with and without attention-deficit/hyperactivity disorder with and without comorbid learning disabilities. Journal of Learning Disabilities, 40(3), 194-202.

Johnstone, S. J., Roodenrys, S., Blackman, R., Johnston, E., Loveday, K., Mantz, S. in Barratt, M. F. (2012). Neurocognitive training for children with and without AD/HD. ADHD Attention Deficit and Hyperactivity Disorders, 4(1), 11-23.

Johnstone, S. J., Roodenrys, S., Phillips, E., Watt, A. J. in Mantz, S. (2010). A pilot study of combined working memory and inhibition training for children with AD/HD. ADHD Attention Deficit and Hyperactivity Disorders, 2(1), 31-42.

Jolles, D. D. in Crone, E. A. (2012). Training the developing brain: A neurocognitive perspective. Frontiers in Human Neuroscience, 6, 76.

Jones, M. R., Katz, B., Buschkuehl, M., Jaeggi, S. M. in Shah, P. (2020). Exploring n-back cognitive training for children with ADHD. Journal of Attention Disorders, 24(5), $704-719$.

Khalili Kermani, F., Reza Mohammadi, M., Yadegari, F., Haresabadi, F., Mehdi Sadeghi, S. in Darouei Haghighi, S. (2016). Working memory training in the form of structured games in children with attention deficit hyperactivity disorder. Iranian Journal of Psychiatry, 11(4), 224-233.

Klingberg, T. (2010). Training and plasticity of working memory. Trends in Cognitive Sciences, 14(7), 317-324.

Klingberg, T., Fernell, E., Olesen, P. J., Johnson, M., Gustafsson, P., Dahlström, K., Gillberg, C. G., Forssberg, H. in Westerberg, H. (2005). Computerized training of working memory in children with ADHD-A randomized, controlled trial. Journal of the American Academy of Child \& Adolescent Psychiatry, 44(2), 177-186.

Klingberg, T., Forssberg, H. in Westerberg, H. (2002). Training of working memory in children with ADHD. Journal of Clinical and Experimental Neuropsychology, 24(6), 781-791.

Kofler, M. J., Rapport, M. D., Bolden, J., Sarver, D. E. in Raiker, J. S. (2010). ADHD and working memory: The impact of central executive deficits and exceeding storage/ rehearsal capacity on observed inattentive behavior. Journal of Abnormal Child Psychology, 38(2), 149-161.

Kühn, S., Romanowski, A., Schilling, C., Lorenz, R., Mörsen, C., Romanczuk-Seiferth, N., Banaschewski, T., Barbot, A., Barker, G., Büchel, C., Conrod, P., Dalley, J., Flor, H., Garavan, H., Ittermann, B., Mann, K., Martinot, J.L., Paus, T., Rietschel, M., . . . Gallinat, J. (2011). The neural basis of video gaming. Translational Psychiatry, 1, članek e53.

Manly, T., Nimmo-Smith, I., Watson, P., Anderson, V., Turner, A. in Robertson I. H. (2001). The differential assessment of children's attention: The Test of Everyday Attention for Children (TEA-Ch), normative sample and ADHD performance. Journal of Child Psychology and Psychiatry, 42(8), 1065-1081. 
Matson, J. L., Rieske, R. in Williams, L. W. (2013). The relationship between autism spectrum disorders and attention-deficit/hyperactivity disorder: An overview. Research of Developmental Disabilities, 34(9), 2475-2484.

McGrath, L. M., Pennington, B. F., Shanahan, M. A., SanterreLemmon, L. E., Barnard, H. D., Willcutt, E. G., DeFries, J. C. in Olson, R. K. (2011). A multiple deficit model of reading disability and attention-deficit/hyperactivity disorder: Searching for shared cognitive deficits. Journal of Child Psychology and Psychiatry, 52(5), 547-557.

Mezzacappa, E. in Buckner, J. C. (2010). Working memory training for children with attention problems or hyperactivity: A school-based pilot study. School Mental Health. A Multidisciplinary Research and Practice Journal, 2(4), 202-208.

Mihevc, N. in Vervega, D. (2019). Sopojavnost duševnih motenj in diferencialno diagnostične dileme pri spektroavtističnih motnjah [Comorbidity of mental disorders and dilemmas of differential diagnostics for autism spectrum disorders]. V P. Janjušević (ur.), Komorbidnost psihosocialnih motenj pri otrocih in mladostnikih [Comorbidity of psychosocial disorders in children and adolescents] (str. 8-35). Svetovalni center za otroke, mladostnike in starše Ljubljana.

Mohammadi, M. R., Zarafshan, H., Khaleghi, A., Ahmadi, N., Hooshyari, Z., Mostafavi, S. A., Ahmadi, A., Alavi, S. S., Shakiba, A. in Salmanian, M. (2019). Prevalence of ADHD and its comorbidities in a population-based sample. Journal of Attention Disorders, 1058-1067.

Nigg, J. T. (2005). Neuropsychologic theory and findings in attention-deficit/hyperactivity disorder: The state of the field and salient challenges for the coming decade. Biological Psychiatry, 57(11), 1424-1435.

Prins, P. J. M., Dovis, S., Ponsioen, A., Ten Brink, E. in van der Oord, S. (2011). Does a computerized working memory training with game elements enhance motivation and training efficacy in children with ADHD? Cyberpsychology, Behavior, and Social Networking, 14(3), 115-122.

Rapport, M. D., Alderson, R. M., Kofler, M. J., Sarver, D. E., Bolden, J. in Sims, V. (2008). Working memory deficits in boys with attention-deficit/hyperactivity disorder (ADHD): The contribution of central executive and subsystem processes. Journal of Abnormal Child Psychology, 36(6), 825-837.

Rapport, M. D., Orban, S. A., Kofler, M. J. in Friedman, L. M. (2013). Do programs designed to train working memory, other executive functions, and attention benefit children with ADHD? A meta-analytic review of cognitive, academic, and behavioral outcomes. Clinical Psychology Review, 33(8), 1237-1252.

Roberts, W., Milich, R. in Barkley, R. A. (2018). Primary symptoms, diagnostic criteria, subtyping, and prevalence of ADHD. V R. A. Barkley (ur.), Attention-deficit hyperactivity disorder: A handbook for diagnosis \& treatment (4. izd., str. 51-80). The Guilford Press.

Rutledge, K. J., van den Bos, W., McClure, S. M. in Schweitzer, J. B. (2012). Training cognition in ADHD: Current findings, borrowed concepts, and future directions. Neurotherapeutics, 9(3), 542-558.
Shalev, L., Tsal, Y. in Mevorach, C. (2007). Computerized progressive attentional training (CPAT) program: Effective direct intervention for children with ADHD. Child Neuropsychology, 13(4), 382-388.

Solanto, M. V. (2018). Executive function deficits in adults with ADHD. V R. A. Barkley (ur.), Attention-deficit hyperactivity disorder: A handbook for diagnosis \& treatment. (4. izd., str. 256-266). The Guilford Press.

Sonuga-Barke, E. (2005). Causal models of attention-deficit/ hyperactivity disorder: From common simple deficits to multiple developmental pathways. Biological Psychiatry, 57(11), 1231-1238.

Sonuga-Barke, E. (2011). Editorial: ADHD as a reinforcement disorder - Moving from general effects to identifying (six) specific models to test. Journal of Child Psychology and Psychiatry, 52(9), 917-918.

Sonuga-Barke, E., Brandeis, D., Holtmann, M. in Cortese, S. (2014). Computer-based cognitive training for ADHD: A review of current evidence. Child and Adolescent Psychiatric Clinics, 23(4), 807-824.

Steiner, N. J., Sheldrick, R. C., Gotthelf, D. in Perrin, E. C. (2011). Computer-based attention training in the schools for children with attention deficit/hyperactivity disorder: A preliminary trial. Clinical Pediatrics, 50(7), 615-622.

van der Donk, M., Hiemstra-Beernink, A. C., Tjeenk-Kalff, A., van der Leij, A. in Lindauer, R. (2015). Cognitive training for children with ADHD: A randomized controlled trial of cogmed working memory training and 'paying attention in class'. Frontiers in Psychology, 6, 1081.

van der Oord, S., Ponsioen, A. J. G. B., Geurts, H. M., Ten Brink, E. L. in Prins, P. J. M. (2014). A pilot study of the efficacy of a computerized executive functioning remediation training with game elements for children with ADHD in an outpatient setting: Outcome on parentand teacher-rated executive functioning and ADHD behavior. Journal of Attention Disorders, 18(8), 699-712.

van Dongen-Boomsma, M., Vollebregt, M. A., Buitelaar, J. K. in Slaats-Willemse, D. (2014). Working memory training in young children with ADHD: A randomized placebo-controlled trial. Journal of Child Psychology and Psychiatry, 55(8), 886-896.

Willcutt, E. G., Doyle, A. E., Nigg, J. T., Faraone, S. V. in Pennington, B. F. (2005). Validity of the executive function theory of attention-deficit/hyperactivity disorder: A meta-analytic review. Biological Psychiatry, 57(11), 1336-1346.

Willcutt, E. G. in Pennington, B. F. (2000). Psychiatric comorbidity in children and adolescents with reading disability. Journal of Child Psychology and Psychiatry, 41(8), 1039-1048.

Willis, S. L. in Schaie, K. W. (2009). Cognitive training and plasticity: Theoretical perspective and methodological consequences. Restorative Neurology and Neuroscience, 27(5), 375-389. 